\title{
シンポジウム（1）劇症肝焱に対する血漿交換療法：何回まで施行すべきか
}

\section{S1-1 劇症肝不全に対する血漿交換療法の功罪}

江口 $\quad$ 晋 $^{1}$, 川添 康 ${ }^{1}$, 蒲原 行雄 ${ }^{1}$
東 $\quad$ 尚 $^{1}$, 藤岡ひかる ${ }^{1}$, 古井純一郎 ${ }^{1}$
兼松 隆之 ${ }^{1}$
('長崎大学第 2 外科 $)$

本邦では劇症肝不全 (FHF)の治療として血漿交換療 法 $(\mathrm{PE})$ が主に施行されている.PEにより凝固因子, オプソニン蛋白は補充可能であるが，その効果は短く, 予後への影響は明らかではない. 今回，FHFに対する 血漿交換療法の功罪を明らかにする目的で以下の検討 を行った。

〔症例：垔急性劇症肝不全患者での血漿交換療法の 限界了症例：17歳, 男性. 入院時, PT $8 \%, \mathrm{~T} . \mathrm{Bil}$ $11 \mathrm{mg} / \mathrm{d} l$ で昏睡 2 度. 亜急性 FHF の診断で血槳交換 8 回, CHF 5 回の血液浄化を施行. しかし肝不全改善 なく，発症から28日目に生体部分肝移植を施行。移植 前の血獎 HGF，TGF- $\beta$ は，上記血液浄化により一時 的に低下するものの異常高值が続き，移植後はともに 低下した。摘出肝は $470 \mathrm{~g}$ (標準肝容積の $40.7 \%$ )で肝再 生像 (PCNA 陽性細胞) は全く認められなかった。肝内 HGF は肝細胞内 $(+), c-m e t$ は肝細胞膜上および内 $(+), \mathrm{TGF}-\beta$ は肝細胞内 $(+)$, 肝細胞, 浸潤リンパ 球にFas $(-)$, Fas-ligand (-), 肝内アポトーシス $(-)$. 本症例では, 血液浄化療法は病的肝再生に効果 を示していなかった。

【実験：肝再生に対する血液浄化の影響〕血液浄化の 肝再生に対する直接的な影響を追求する目的で以下の 実験を行った. Lewis ラットを用い $(n=36)$, 全例に標 準 $68 \%$ 肝切除術を施行. 血液交換群(交換群)には, 術 後 6,12 時間に各々 $20 \mathrm{~m} l$ の正常同種血液交換を施行. 24，48，72時間後にラットを犠牲死させ，血算，血液 生化, 肝重量, PCNA LI, 肝細胞增殖因子(HGF) を 解析. 対照群では術後 6,12 時間に各々 $20 \mathrm{~m} l$ の肝切 除後同時期の血液で血液交換を施行(対照群).

〔結果〕交換群，対照群間で各時間における血算に有 意差なし。肝酵素は $24,48,72$ 時間で交換群にて有意 に低値. $\mathrm{NH}_{3}, \mathrm{PT}$ も同様に交換群にて改善. しかし, 24，48時間の肝再生率は交換群が対照群より低值 (24 h : $80 \pm 16$ vs $36 \pm 1 \%$, $48 \mathrm{~h}: 105 \pm 15$ vs $75 \pm 11 \%$, $\mathrm{p}<0.05)$. PCNA LI も交換群では対照群より有意に低 值 (24h: $12 \pm 2 \mathrm{vs} \mathrm{:} 38 \pm 3 \%, \mathrm{p}<0.05)$. 肝切除 6 時 間後の $\mathrm{HGF}$ 値は注入同種血液より有意に高値 $(6 \mathrm{~h}$ :
$1.1 \pm 0.5 \mathrm{vs} 0.1 \pm 0.1 \mathrm{ng} / \mathrm{m} l, \mathrm{p}<0.05)$. 肝切除後の血 液浄化は血液生化学的異常を改善する “功”があった が, 肝再生を遅延させる “罪”も窥われた。後者の原 因として, HGF 等内因性肝再生促進因子の岥失が考え られた。

〔結語〕不全肝再生の点では PE の効果は低く, 肝再 生促進因子補充等との組み合わせも考慮する必要があ ると考えられた。 また, 肝再生に必要な因子を失うこ となく, 肝補助を施行できる他療法開発の今後の発展 が望まれる。

\section{S1-2 劇症肝炎における人工肝補助療法の施行回数と 予後に関する検討}

松岡 俊一 ${ }^{1}$, 鈴木 壱知 ${ }^{1}$, 松岡千花子 ${ }^{1}$ 小川 眞広 ${ }^{1}$, 後藤 伊織 ${ }^{1}$, 荒川 泰行 $^{1}$

渡辺 善広 ${ }^{2}$, 高野 靖悟 $^{2}$, 長尾 建 $^{3}$

矢崎 誠治 ${ }^{3}$, 林 成之 ${ }^{3}$

( ${ }^{1}$ 日本大学第 3 内科, ${ }^{2}$ 同 第 3 外科, ${ }^{3}$ 同 救急医学科)

索引用語：劇症肝炎, 人工肝補助療法, 生体部分肝 移植

〔目的〕劇症肝炎は予後不良な疾患であり, 特に亜急 性型では生存率 $20 \%$ 以下にすぎず，比較的予後良好と される急性型もその救命率は低下傾向にある. 現在本 邦では血槳交換法を中心とした肝補助療法が集中治療 の核をなしている. 今回我々は, 当施設における劇症 肝炎に対する集中治療の現状を検討し, その内最も重 要と思われる人工肝補助療法の施行回数について検討 追加した。

〔方法〕平成 9 年10月から平成11年 4 月まで, 第12回 犬山シンポジウムの診断基準に従い劇症肝炎と診断し, 救命救急センターで管理した10例について検討した。 内訳は急性型 3 例, Acute on chronic 2 例, 亜急性 型 5 例で, 原因は HAV 2 例, HBV 3 例, 薬剤 1 例, 不明 4 例であった。全例に感染症・消化管出血・ 低血糖・D.I.C・腎不全・脳浮腫などの合併症対策 と, 肝再生促進に関する治療をした。ステロイド剤は 3 例に, 特殊組成アミノ酸製剤は 6 例に, また肝微小 循環障害の改善目的に AT-III製剤を 6 例に使用した。 また全例に早期より必須物質補充および血中毒性物質 除去の目的に, 人工肝補助療法 ALS (Continuous Plasma Exchange: CPE, Hemodiafiltration: 
$60: 210$

肝

$\mathrm{HDF})$ を併用した。これら強力な集中治療に改善をみな かった 2 例の亜急性型劇症肝炎に対し生体部分肝移植 (LRLT)を施行した. ALS は CPE と HDF を直列に連 結して施行し，その際の抗凝固薬はメシル酸ナファモ スタットを用い, ACT を測定して正常值の1.4〜1.5倍 となるようにコントロールした. CPEの血漿分離器は OP-08W を使用し, FFP 40u〜 70u を 6〜8 時間かけ て施行した. 血液流量 $\left(\mathrm{Q}_{\mathrm{B}}\right)$ は $\mathrm{HDF}$ の $\mathrm{Q}_{\mathrm{B}}$ を上回らない ように70〜 $90 \mathrm{~m} l / \mathrm{min}$ に設定した. HDF のダイアライ ザーは PAN 膜を用い, 置換液は重炭酸バッファー液を $20 \mathrm{l} / \mathrm{day}$ 以上使用した。 $\mathrm{Q}_{\mathrm{B}}$ は $100 \sim 120 \mathrm{~m} l / \mathrm{min}$, 透析 夜 $\left(\mathrm{Q}_{\mathrm{D}}\right)$ は $1000 \mathrm{~m} l / \mathrm{hr}$, 補 (置換) 液流量 $\left(\mathrm{Q}_{\mathrm{F}}\right)$ は $2000 \mathrm{ml}$ hr とした. CPE/HDF は 3 回 (3 日間連日)を 1 クール とし, 保険適応範囲内を意識して原則として 2 クール (6 回) か, 1 クール施行後 2 日間連日を 2 回までとし，続行に関してはPT・HPT・T.B・D.B/ T.B・AKBR・Coma gradeを参考にした (Fig.1).
41 巻 3 号 $(2000)$

しかし実際には，10例中 2 例に 8 回以上の施行を要し た. なお, 入院時において予後予測を, 高橋らの式, 武藤らの式, 第22回急性肝不全研究会の肝移植ガイド ラインの 3 通りで行った。

〔結果〕救命率は急性型 $100 \%(3 / 3)$, Acute on chronic $100 \%(2 / 2)$, 亜急性型 $40 \%(2 / 5)$ で, 全体で $70 \%$ あった。 入院時全例ドナー肝確保にあたったが 確保率は $50 \%(5 / 10) て ゙$, 実際には 2 例に LRLT を施行 した. その内, 1 例は生存, 1 例は移植後17日目に肝 動脈血栓症の悪化から肝不全となり死亡した. ALS 施 行回数別の救命率は, 1 クール ( $2 \sim 3$ 回) が 3 例で 2 例生存 $(66.7 \%), 2$ クール ( $4 \sim 6$ 回) が 4 例で全例生 存(100\%)であり 2 クール以内の生存率は $85.7 \%$ でっ た. 7 回・ 8 回・ 9 回施行例が各々 1 例ずつあり,す べて非A非 B 型の亜急性型劇症肝炎で, 生存は LRLT

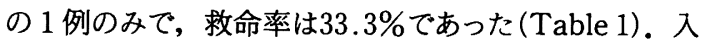
院時予後予測は, 高橋らの式が $90 \%$, 武藤らの式が

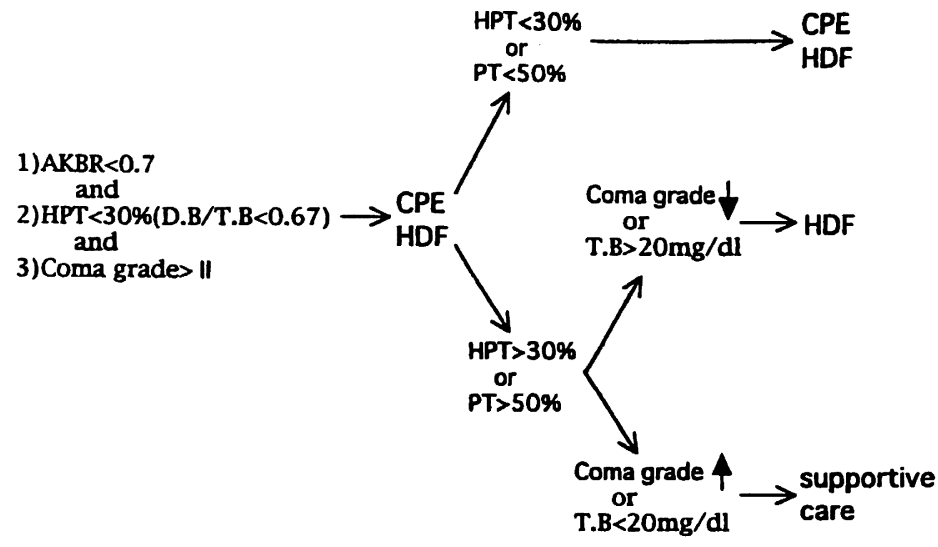

Fig. 1 Artificial Liver Support

Table 1 Clinical features in patients with fulminant hepatitis

\begin{tabular}{|c|c|c|c|c|c|c|c|c|}
\hline Pt. No & Age.Sex & Type & Etiology & Prognosis & LRLT & $\mathrm{CPE}$ & SR & \\
\hline 1 & $66 \mathrm{M}$ & SA & & Death & & 2 & \multirow{3}{*}{$66.7 \%$} & \multirow{7}{*}{$85.7 \%$} \\
\hline 2 & $40 \mathrm{M}$ & Ac & $\mathrm{HBV}$ & Alive & & 3 & & \\
\hline 3 & $66 \mathrm{~F}$ & $\mathrm{AOC}$ & HBV & Alive & & 3 & & \\
\hline 4 & $51 \mathrm{M}$ & Ac & $\mathrm{HAV}$ & Alive & & 4 & \multirow{4}{*}{$100 \%$} & \\
\hline 5 & $59 \mathrm{~F}$ & Ac & $\mathrm{HAV}$ & Alive & & 5 & & \\
\hline 6 & $54 \mathrm{M}$ & $\mathrm{SA}$ & & Alive & & 5 & & \\
\hline 7 & $33 \mathrm{~F}$ & $\mathrm{AOC}$ & $\mathrm{HBV}$ & Alive & & 6 & & \\
\hline 8 & $31 \mathrm{~F}$ & $\mathrm{SA}$ & & Death & 0 & 7 & \multirow{3}{*}{$33.3 \%$} & \\
\hline 9 & $58 \mathrm{~F}$ & SA & & Death & & 8 & & \\
\hline 10 & $16 \mathrm{~F}$ & SA & Drug & Alive & $\bigcirc$ & 9 & & \\
\hline
\end{tabular}

LRLT : living related liver transplantation, SR : survival rate, Ac: acute, SA : subacute, AOC : acute on chronic 
$80 \%$ ，肝移植ガイドラインが $90 \%$ に一致をみた．ALS $7 \cdot 8 \cdot 9$ 回施行例はすべての予後予測式で「死亡」 と判定されており, 実際に死亡例, LRLT 施行例が多 い傾向を認めた。

〔考察ならびに結語〕今回の検討では, 劇症肝炎のう ち, $\mathrm{CPE} / \mathrm{HDF}$ を含む内科的集中治療で救命し得るも のは急性型で, かつ HAV, HBV など原因の明らかな ものに多く, ほほ現在の保険適応範囲内の施行回数 (CPE は入院一連につき 7 回, HDF10回/月で 3 力月ま で)で満足されるという結果を得た。しかし，非 $\mathrm{A}$ 非 $\mathrm{B}$ 亜急性型で，かつ信憑性のある予後予測式で「死亡」 と判定された症例は施行回数を増やしても予後不良で, 内科的治療の限界があり早期に肝移植を考慮すべきと 考えられる. 今後の脳死肝移植症例の増加が望まれる が，実際の移植医療ではドナー肝確保が困難であるこ とより，当面は LRLT が肝移植の核をなすものと考え ろ. 肝移植適応の劇症肝炎にとって CPEも HDF も肝 移植までの Bridge use としての人工肝補助装置にすぎ ない.しかし，肝移植までの生命維持に努めるのであ ればその施行回数は限定されるものではないと結論づ けたい。

文 献：1）鈴木一幸, 佐藤俊一：我が国における劇 症肝炎の治療の現況と将来. 肝臓 $39-2: 57-61$, 1998 2) 杉原潤一, 石木佳英, 内藤智雄, 他: 劇症 肝炎における肝移植適応のガイドライン(案)。肝臓 $37: 757-758,1996$ 3）鈴木一幸, 遠藤龍人, 坂下 佳子, 他: 劇症肝炎と肝移植をめぐる問題点. 肝胆膵 33:35-41, 1996 4) Fujiwara K, Okita K, Akamatsu K, et al : Antithrombin 3 Concentrate in the Treatment of Fulminant Hepatic Failure. Gastroenterol Jpn 23:423-427, 1989 5) M. Yoshiba, K. Inoue, K. Sekiyama, et al : Favorable effect of new artificial liver support on survival of patients with fulminant hepatic failure. Artificial Organs $20: 1169-1172,1996$

\section{S1-3 劇症肝炎における血漿交換療法の治療成績一施 行回数の検討一}

菊池 英亮 ${ }^{1}$, 増井 一弘 ${ }^{2}$, 中谷 吉宏 ${ }^{1}$ 竹内 洋司 ${ }^{1}$, 植村 正人 ${ }^{1}$, 福井 博 ${ }^{1}$

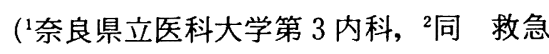
科)

索引用語：劇症肝炎, 血槳交換, 持続血液滤過透析 【目的〕劇症肝炎の治療として, 血漿交換療法 (PE) が積極的に行われているが，保険診療では，PEの施行
回数は一連につき 7 回までとされている.一方で, 肝 移植が劇症肝炎に対しても行われるようになり，PEを 何回まで施行すべきかを明らかにすることが求められ ている. そこで, 劇症肝炎救命に必要な PE の施行回数 を明らかにする目的で, 劇症肝炎に対して行われた PE および持続血液滤過透析(CHDF)の効果について, PE 施行回数に注目して検討した.

【対象および方法〕対象は当科で PEを施行した劇症 肝炎32例および遅発性肝不全(LOHF) 2 例の計34例で ある. 対象症例に対して行われた PE 施行回数を検討 し, $\mathrm{PE}$ 施行回数が 7 回までの群( $\mathrm{PE} \leqq 7$ 回群, 22 例) と $\mathrm{PE}$ 施行回数が 8 回以上の群 $(\mathrm{PE} \geqq 8$ 回群, 12 例)に わけ, 臨床像, プロトロンビン活性 (PT) の推移を生命 予後別に検討した。 さらに CHDF 併用による効果につ いても検討を加えた。

〔成績〕 対象症例の病型別生存率は急性型 $47.7 \%$, 亜急性型 $23.1 \%$ で, LOHF は 2 例とも死亡した. 平均 $\mathrm{PE}$ 施行回数は急性型6.6回, 亜急性型10.2回で亜急性 型で多い傾向にあった. $\mathrm{PE \leqq 7}$ 回群の生存率は 22 例中 8 例(36.4\%)であったが, $\mathrm{PE} \geqq 8$ 回群においても12例 中 4 例 $(33.3 \%)$ に生存が得られていた. $\mathrm{PE} \geqq 8$ 回群の 生存 4 例中 3 例に CHDF を, 1 例に HD を併用してい た.また, $\mathrm{PE} \leqq 7$ 回群と $\mathrm{PE} \geqq 8$ 回群の脳症発現時に おける総ビリルビン直接ビリルビン, PT 活性に差は認 めなかった. $\mathrm{PE} \leqq 7$ 回群における $\mathrm{PE}$ 施行翌日早朝の PT 活性は, 生存例に扔いて PE 2 回施行後から死亡例 に比べて有意に高值をとるようになり, PE 3 回後翌日 の PT 活性は, 生存例で42.1 $12.2 \%$ と生存例で有意に高値であった。一方, $\mathrm{PE} \geqq 8$ 回群における生存例の PT 活性は, PE 9 回施行後翌日 で初めて死亡例に比べて有意に高值をとった(Fig.1). 急性肝不全研究会肝移植ガイドライン(案)の予後予測 にあてはめると, $\mathrm{PE} \geqq 8$ 回群の生存例は全例, 脳症発 現時, 治療開始 5 日後のいずれにおいても死亡と判定 された. CHDF を併用したのは 5 例で, そのうち 3 例 (60\%)で生存が得られた.さらに, CHDF 施行により 死亡例も含め全例で脳症改善が得られた. 死亡 2 例の 脳症発現時から死亡に至るまでの日数は, それぞれ95 日，43日で，CHDF 非施行例 (平均23.9日)に比べ長い 傾向にあった.

【考察】劇症肝炎の治療成績は肝補助療法が積極的 に行われているにもかかわらず満足のいくものではな く, とくに亜急性型の生存率は低いままである. 一方, 劇症肝炎に対しても肝移植がなされるようになり, 劇 


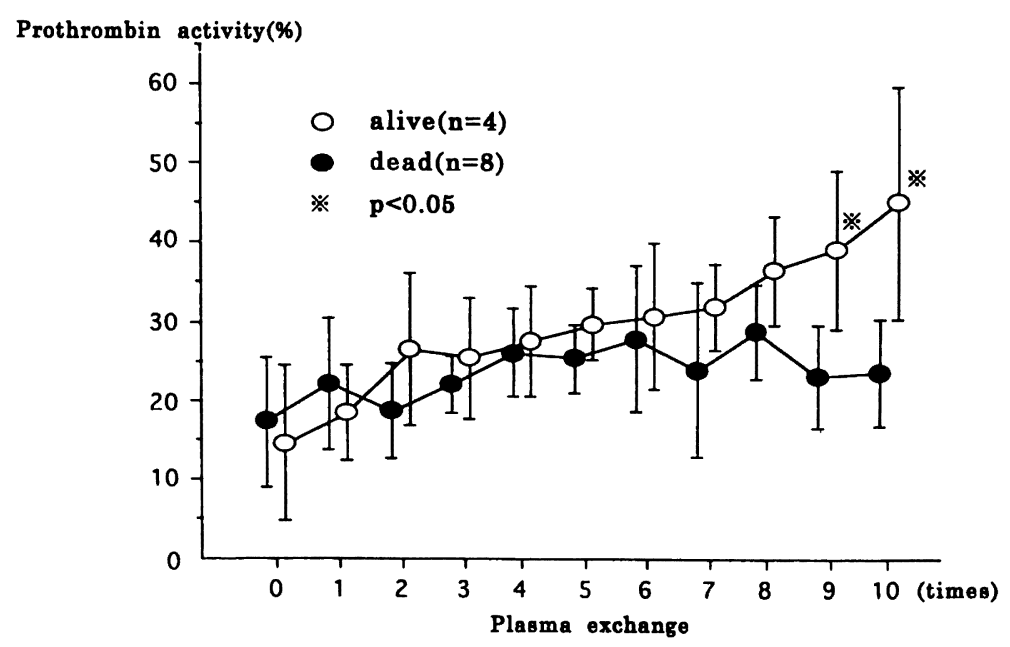

Fig. 1 Changes of Prothorombin activity after plasma exchange in patients with fulminant hepatitis

症肝炎に対する PE の施行回数を一連につき 7 回までと する現在の保険診療上の制約を再検討する必要がある と思われる.われわれの検討では, 予後予測で死亡と 判定された例においても血液净化療法や他の肝補助療 法を積極的に行うことにより徐々に PT 活性が上昇し, 生存につながった例があり,この際の PE 施行回数は少 なくとも 9 〜回必要であった. 劇症肝炎の生存率を 向上させるには, 死亡と予測された例に対しても血液 净化療法を中心とした肝補助療法を積極的に行いつつ, 患者の病態によっては時期を逸することなく肝移植に 踏み切るための準備をすることが肝要であると考える. この際には，PEと CHDFの併用は肝移植までの Bridge use としても有用であると考えられた．また， 劇症肝炎の予後予測をさらに精度の高いものにするこ とも急務であると考えられた。

文 献：1）鈴木一幸, 佐藤俊一：我が国における劇 症肝炎の治療の現況と将来. 肝臓 $39: 57-60,1998$ 2) 橋倉泰彦, 池上俊彦, 寺田 克, 他: 生体肝移植 の現状と将来. 現代医療 $30 ： 115-118,1998$ 3) 杉原潤一, 石本佳英, 内藤智雄, 他: 劇症肝炎におけ る肝移植適応のガイドライン(案). 肝蔵 $37: 757-$ 758, 1996

\section{S1-4 劇症肝资に対する血䏺交換療法の意義と限界}

石井 邦英 ${ }^{1}$, 神代 龍吉 ${ }^{1}$, 古賀郁利子 ${ }^{1}$ 福泉公仁隆 ${ }^{1}$, 佐田 通夫 ${ }^{1}$, 坂本 照夫 $^{2}$ 加来 信雄 $^{2}$

( ${ }^{1}$ 久留米大学第 2 内科, ${ }^{2}$ 同 救急医学)

索引用語：劇症肝炎, 血槳交換療法, 肝移植

〔背景〕劇症肝炎は公費負担の特定疾患であるが，内 科的な主な治療法である血槳交換療法 (以下, PE)は一 連につき 7 回, 持続血液滤過透析 (以下, $\mathrm{CHDF}$ ) は月 に10回が保険適応の限界である。しかしながら，本邦 では脳死肝移植が充分確立されたとは言えず, 血液净 化法を中心とした内科的集中治療に依存しているのが 現況である。そこで, 劇症肝炎に対する血液浄化法, 特にPEの意義および限界について検討した。

【対象〕当施設で最近 7 年間に経験した劇症肝炎 18 例 を対象とした。平均年齢は46.2歳 (19歳から70歳まで), 男性が11例, 女性が 7 例であり, 病型分類では亜急性 型が13例, 急性型が 5 例であり, 病因では非 $\mathrm{A}$ 非 $\mathrm{B}$ 非 C 型が11例と最も多く, HBV と薬剤性が各々 3 例ずつ で, HCV が原因と考えられるものが 1 例であった。

〔目的と方法〕対象とした劇症肝炎18例の総医療費を 診療報酬請求明細書より調べ, 血液浄化法を中心とし た集中治療と医療費の関係を明らかにするとともに, その有効性や問題点より PE の適切な施行回数があるか 否かを検討した. さらに, PE の延命効果を調べるため に, 当施設で過去に経験した非 $\mathrm{A}$ 非 $\mathrm{B}$ 非 $\mathrm{C}$ 型劇症肝炎 の死亡28例において PE 実施の有無と生存期間との関係 
を検討した。

【結果〕劇症肝炎・亜急性型では，13例中12例が死 亡し救命し得たのは 1 例 $(7.7 \%)$ のみであった。劇症肝 炎・急性型では 5 症例中 B 型の 2 例 $(40 \%)$ が生存した。 死亡した15症例において $\mathrm{PE}$ および CHDF の延命効果 をみるために生存期間を比較した結果を表 1 に示す。 PE を実施し死亡した13症例での PE 回数は平均9.8回

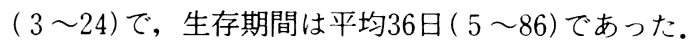
一方, $\mathrm{PE}$ 末実施死亡 2 症例の生存期間は平均 9.5 日 $(9 \sim 10)$ であり, 有意差が認められた。しかしながら, CHDF 未実施死亡 6 例と CHDF 実施死亡 9 例を比較 しても生存期間には差は認められなかった。図 1 に示 すように $\mathrm{PE}$ 施行生存 3 症例の施行回数は平均 9.3 回 $(8,9,11)$ であり, 死亡13症例の施行回数は平均 9.8 回であり, PE12回以上の実施例では生存例はみられな かった。ささらに, PE 実施16例において, 死亡生存の判 別分析を行うと境界点は9.4回であった，過去に経験し た非 $\mathrm{A}$ 非 $\mathrm{B}$ 非 $\mathrm{C}$ 型劇症肝炎死亡28症例の検討では, 脳 症 II 度から死亡までの期間は, PE 実施例 $(\mathrm{n}=17)$ が平 均16.5日, $\mathrm{PE}$ 非実施例 $(\mathrm{n}=11)$ は平均 6.8 日で, 有意 差 $(\mathrm{p}<0.005)$ が認められた。医療費に関しては平均 33 日の入院期間で 1 日当たり約 32 万円，総医療費では平 均 880 万円を要していた。また，PEを 12 回以上実施し た 5 症例中 4 例の総医療費は1000万円を超えていた。

図 2 に示すように最も医療費を要した例でば79日間の 内科的集中治療で2330万円を要しており，PEおよび CHDF でその約 $52 \%$ を占めており，血液製剤と DIC 治 療薬を加えると約 $71 \%$ に達していた。

〔考案〕血液浄化法を中心とした内科的な集中治療に もかかわらず劇症肝炎亜急性型の救命率は改善してお らず，1997年度の全国集計では14.8\%であった。劇症 肝炎に対して各種の予後予測式が作成され，肝移植を 念頭にわいて内科的集中治療が行われているが，医療 費の問題からもその限界が指摘されている21. また, 劇 症肝炎における予後予測は, 肝性昏睡出現時のデーター を解析するものであり，亜急性型では脳症発現までに 長期間を要し，脳症出現後は集中治療にもかかわらず 2 週間以内の短期間に死亡する例も多く，これらの症 例では肝移植まで延命出来ないと考えられる ${ }^{3 !}$. したがつ て, 劇症肝炎亜急性型では意識障害の出現以前に重症 化を予測することも重要である4).今回の検討から劇症 肝炎に対する PE の回数は，一連につき 10 回程度が妥当 と考えられた。また，PE は生存期間を明らかに延長さ せ，肝移植までの Bridging Therapy としての有用性
表 1 死亡15例における延命効果の比較

\begin{tabular}{cccc}
\hline $\begin{array}{c}\text { 血液浄化法 } \\
\text { の有無 }\end{array}$ & 例数 & \multicolumn{2}{c}{$\begin{array}{c}\text { 生存期間 } \\
(\text { 日 }\end{array}$} \\
\hline $\mathrm{PE}(-)$ & $\mathrm{n}=2$ & $(9 \sim 10)$ & $9.5 \pm 0.5$ \\
$(+)$ & $\mathrm{n}=13$ & $(5 \sim 86)$ & $36.0 \pm 28.1^{*}$ \\
\hline $\mathrm{CHDF}(-)$ & $\mathrm{n}=6$ & $(9 \sim 86)$ & $40.2 \pm 30.5$ \\
$(+)$ & $\mathrm{n}=9$ & $(5 \sim 79)$ & $27.3 \pm 24.3$ \\
\hline & & & \\
& & &
\end{tabular}

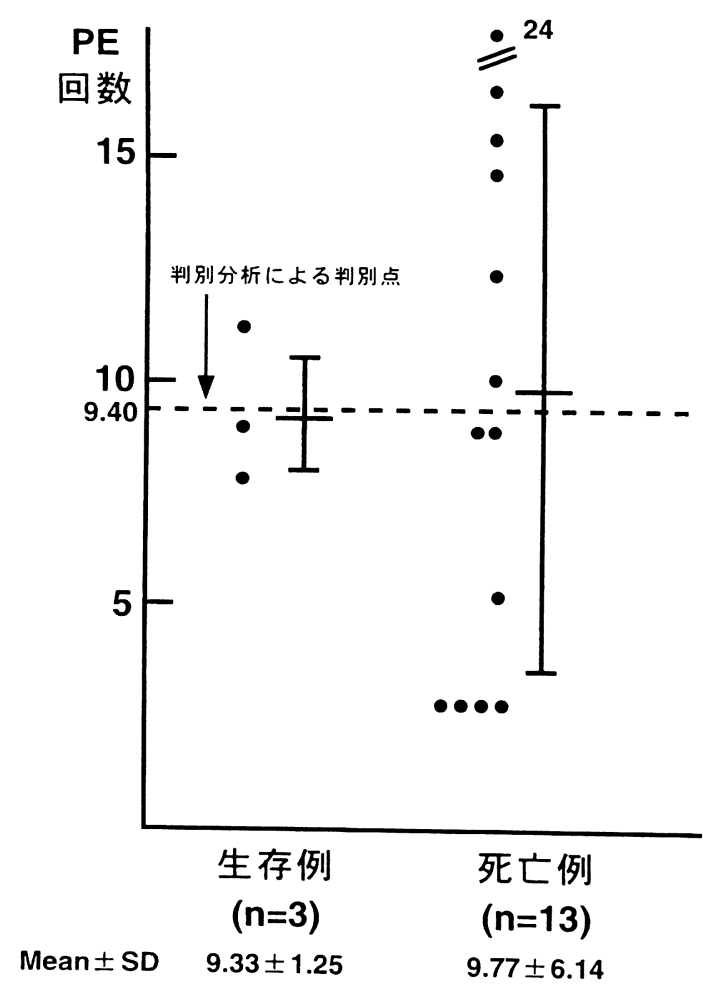

図 1 血獎交換回数の比較

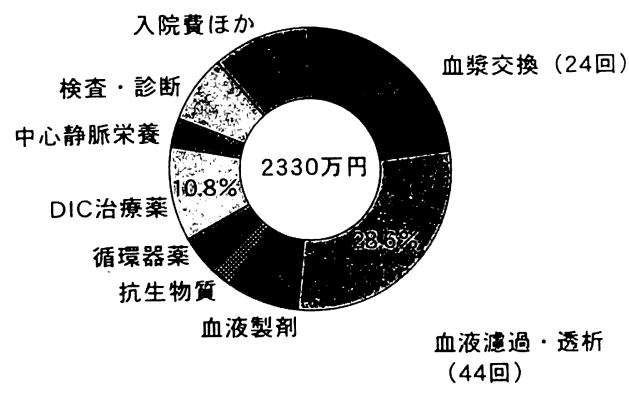

図2 NANBNC Fulminant hepatitis (24) male-Died 79 days after admission 
が認められた。しかし，12回以上の PE は肝移植と同額 の費用を要し救命にも限界がみられた。したがって， 劇症肝炎・亜急性型で死亡が予測された症例では早期 に肝移植を考慮すべきであり，十分なインフォームド コンセントのもとに家族の同意を得た治療法を選択す る必要がある。

文 献：1）光岡正純, 米田利弘, 原野澄江, 他：劇 症肝炎亜急性型における救命医療と Futility の一症例. 日本救命医療研究会誌 $10: 187-194,1996$ 2) 石 井邦英, 神代龍吉, 古賀郁利子, 他：劇症肝炎におけ る予後因子と cost-benefit-analysis からみた集中治療 の限界. 肝蔵 $39: 68-72,1998$ 3) 神代龍吉, 石 井邦英, 佐田通夫：生体肝移植までの Bridging Therapy としての血槳交換療法. 消化器科 $28: 90-93$, 1999 4) Kumashiro R, Sata M, Koga Y, et al: Selection of Prognotic Factors of Acute Hepatitis Type Non-A Non-B for Patient Listing for Liver Transplantation, Transplantation $64: 418-421$, 1997

\section{S1-5 劇症肝炎 $(\mathbf{F H})$ に対する血獎交換 $(\mathrm{PE})$ 実施回数 の検討}

平野 剛 ${ }^{1}$, 平澤 博之 ${ }^{1}$, 菅井 桂雄 ${ }^{1}$

織田 成人 ${ }^{1}$, 志賀 英敏 ${ }^{1}$, 中西加寿也 ${ }^{1}$

北村 伸哉 1 , 貞広 智仁 ${ }^{1}$, 川上 雅之 ${ }^{1}$

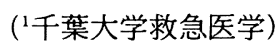

〔目的〕 PE は人工肝補助療法 (ALS) として, FH の 救命率の向上に大きな役割を果たしてきた。しかし亜 急性型や肝萎縮の認められる症例の救命率は極めて低 く, 保存的治療のみでは限界がある. かかる症例に対 しては早期より肝移植の適応を考慮すべきであるが, 肝移植を行う場合でも ALS としての PE は bridge use として不可欠である。現在 $\mathrm{FH}$ に対する $\mathrm{PE}$ は健康保険 上「実施回数は, 一連につきおおむね 7 回を限度とし て算定する」とされ，実施回数が制限されている．今 回我々は $\mathrm{FH}$ に対する $\mathrm{PE}$ の実施回数につき当科におけ る治療成績を用いて，健康保険法の規定および，1996 年に提案された日本急性肝不全研究会肝移植適応ガイ ドラインが適切であるかどうかについて検討した.

〔対象及び方法〕1988年 4 月から1999年 3 月までに当 院 ICU に入室した FH46例(急性型23例うち生存例 13 例, 亜急性型23例うち生存例 3 例) を対象に, 生存例お よび死亡例の PE 実施回数, 7 回を上回る PE の実施 症例の転帰, ガイドライン死亡予測例及び生存予測例
の PE 実施回数, ガイドラインによる再予測時 PE 実施 回数につきそれぞれ検討した。

【結果】生存例の PE 実施回数は $4.6 \pm 3.1$ 回, 死亡 例の $\mathrm{PE}$ 実施回数は7.4 4 4.1回と死亡例で有意に多 かった. またガイドラインで肝移植適応であった37例 の $\mathrm{PE}$ 実施回数 5.8 回に対して, 肝移植非適応 9 例は 3.6回と少ないものの有意差は認められなかった. ガイ ドラインによる再予測時までの PE 実施回数につき, 再 予測前に他施設へ移植目的にて転院した 1 例及び再予 測時にすでに死亡していた 9 例を除いた27例について 検討したところ, 平均実施回数は 4.2 回であった。 また 再予測時すでにPE 5 日連続して実施している症例が 13例( $35.1 \%)$ と最も多かった.

〔考察〕死亡例に比して生存例の PE 実施回数は有意 に少なかったものの, 生存例のうち 3 症例においては 7 回を越える PE を実施したのちに救命しえた. また覀 急性型や肝萎縮の認められる症例は早期より肝移植の 適応を考慮すべきであるが, その際の ALS としてのPE は bridge use として不可欠である.しかしガイドライ ンにより移植適応を決定するためには 5 日間の日数が 必要であり多くの症例でその間に PE 5 日連続して実 施している。このため実際に肝移植の登録を行う段階 では健康保険法で認められた PE の実施回数の殆どを終 了してしまっていた．このため当科の移植適応基準で ある1)亜急性型, 2) 急性型で肝萎縮のある場合，3)急 性型で96年ガイドラインで適応ありと予測される場合, を用いることにより速やかに肝移植の登録を行うべき であると考えられた。本基準は再予測を必要としない ため 5 日間の観察期間を短縮することが可能となりそ の間 PEを bridge use として有効に用いることが可能 である。

〔結論〕移植適応, 非適応にかかわらず $\mathrm{FH}$ に対して PE ALS として不可欠である.しかし実施回数につ いては一律に決定することは困難であり, 特に PEを bridge use として用いる際には回数に制限を設けるこ とは倫理的にも問題がある。しかし, 将来的には急性 型, 亜急性型の別によるまた移植適応の有無による $\mathrm{PE}$ 実施回数の制限について検討を加える必要がある. 一 方, 当科の適応基準を用いることにより移植準備に関 わる期間の短縮や PE の実施回数を減ずることが可能で あると考えられた。 


\section{S1-6 生体肝移植までの bridge use としての血漿交換} 療法

\author{
春口 洋昭 ${ }^{1}$, 㴊之上昌平 ${ }^{1}$, 中島 一朗 ${ }^{1}$ \\ 唐仁原 全 ${ }^{1}$, 阿岸 鉄三 ${ }^{1}$, 伊藤 克己 $^{2}$ \\ 白珐 宏司 ${ }^{2}$, 林直諒 ${ }^{3}$, 高崎 健 ${ }^{4}$ \\ 田中 紘一 ${ }^{5}$ \\ ( ${ }^{1}$ 東京女子医科大学第 3 外科, ${ }^{2}$ 同 腎臓 \\ 小児科, ${ }^{3}$ 同 消化器内科, ${ }^{4}$ 同 消化 \\ 器外科, 5 京都大学移植免疫)
}

劇症肝不全の生存率は, 急性型で $54.1 \%$, 覀急性型 で13.4\%と，特に亜急性型では予後不良な疾患であ $\eta^{1)}$,さまざまな人工肝補助療法(ALS) が試みられてい る. ALS として, 血漿交換療法(PE) と血液滤過透析 (HDF) を組み合わせた治療が有用であると報告されて いるが，肝再生が行われなければ救命することはでき ない. 肝移植は肝再生が望めない症例に対する唯一の 治療であり, 生存率も $70 \%$ に達している21. 今回我々は, 生体肝移植までの bridge use としての ALS の有用性 について検討した.

〔対象と方法〕1995年から1998年にかけて，劇症肝不 全に対して施行した生体肝移植症例 9 例(男性 6 例, 女 性 3 例, 年齢 9 か月〜 53歳)における術前の血液浄化療 法を中心に retrospective に検討した.

〔結果〕 7 例が亜急性型, 2 例が急性型であり, 肝不 全の原因は全例とも non- $A$, non- $B$, non- $C$ hepatitis であった。極期の昏睡度は II 度から V 度であったが, 全例で PE+HDF を施行し， 7 例では昏睡度の改善が 認められた。脳症出現から移植までの期間は $5 \sim 40$ 日 (平均15.1 111.7 日) であり, 当科へ入院してから移植 までの期間は $3 \sim 8$ 日(平均5.4土2.0日)であった. PE 施行回数は $1 \sim 24$ 回 (平均 $10.4 \pm 6.6$ 回), $\mathrm{HDF}$ 施行日 数は 2 〜0日 (平均 $11.2 \pm 11.3$ 日)であった。9 例の患 者のうち 4 例が死亡した。死因は敗血症から MOF に 至ったものが 2 例, 再生不良性貧血が 1 例, 肝炎再発 が1例であった. ALS 施行から, 肝移植までの日数は, 生存群 $5 \sim 26$ 日 (平均13.4 18.9 日), 死亡群 $3 \sim 30$ 日 (平均15.5土11.1日)であり, 両群間で有意差を認めな かった。また, 昏睡度 II 度から血液浄化療法開始まで の期間は, 生存群 $0 \sim 7$ 日, 死亡群 $6 \sim 5$ 日であり,
両群間に明らかな差はなかった。術前に感染症, 腎不 全, 消化管出血を合併していた割合はそれぞれ, 死亡 群 $100 \%, 50 \%, 50 \%$, 生存群 $40 \%, 20 \%, 0 \%$ で あった。

〔考察〕生存群と死亡群で, ALS の開始時期および 施行日数, 回数に差がないことが明らかとなった。し かしその一方で, 術前の合併症の有無が移植の成績に 影響を及ぼしたことを考慮すると, 発症後早期の肝移 植が望まれる。

適応基準に関しては, 急性肝不全研究会のガイドラ インが一般的に採用されている。この適応基準を用い れば，脳症出現から 5 日以内に肝移植の適応を決定し， 1 週間以内に移植可能な施設へ転送することができる. 当科での転送後移植までの期間が平均 5.4 日であること から, 脳症出現より14日以内の生体肝移植は可能と考 える.

すなわち劇症肝不全の bridge use としてのPEは, この間連日で行うとしても最高14回となる. 患者の病 態にもよるが, $\mathrm{HDF}$ を併用することで, 連日 PEを施 行せずとも脳症の進行を阻止できるため, 実際 PE は 7 から10回程度で肝移植につなぐことができる. 劇症肝 不全は急激に発症・進行するため, 家族が生体肝移植 の決断を下すまでには, 時間を要することも少なくな い.このような場合は血槳交換の回数を制限するべき ではないが，脳症出現時に患者及び家族に肝移植の可 能性を言及しておくことで, 肝移植決定までの期間を 少しでも短縮することが可能となる.

〔結論〕生体肝移植までのbridge としてのPE＋ HDF は有用であるが，血液浄化療法施行中に合併する 腎障害, 感染症, 消化管出血が移植後の予後を不良に している．移植までの期間を短縮することが重要であ るが，それには脳症出現時より，移植を念頭においた 治療戦略をたてることが必要と考えられた。

文 献：1）武藤泰敏：劇症肝炎における肝移植の適 応. 肝移植適応基準, 市田文弘, 谷川久一編, p4, 国際出版, 1991 2) 杉原順一, 村上啓雄, 内藤智雄, 他：劇症肝炎に対する肝移植の適応. MB Gastro $3(8): 33-40,1993$ 


\section{シンポジウム（2）劇症肝资治療法としての APOLT の意義}

\section{S2-1 劇症肝不全における APOLT の意義}

岸田 明博1, 古川 博之 1 , 大村 孝志 ${ }^{1}$ 松下 通明 ${ }^{1}$, 柳田 尚之 ${ }^{1}$, 藤田 美悧 ${ }^{2}$ 清水 道夫 ${ }^{2}$, 藤堂 省 ${ }^{1}$

( ${ }^{1}$ 北海道大学第 1 外科, ${ }^{2}$ 同 臨床病理)

索引用語：自己肝温存同所性部分肝移植, 劇症肝不 全, 肝再生

〔目的〕APOLT の利点は, 自家肝の機能が充分に回 復し, 移植肝による機能補助が不必要となった時点で 免疫抑制剤が中止できることである ${ }^{1 !}$.しかしながら， 劇症肝不全の誘因となった原疾患の違いや門脈を介す る自家肝への血流量などの因子によって，自家肝の再 生を予測することは困難なことが多い，当科において は現在までに， 3 例の劇症肝不全の症例に対して生体 間 APOLTを施行した。CT スキャンによる肝容積の 測定, 肝生検ならびに GSA (Galactosyl serum albu$\min )$ シンチにて自家肝の再生過程を経時的に観察し, APOLT の意義ならびに自家肝の再生に関する因子に ついて検討した。

〔症例〕症例 1 は B 型肝炎による22歳の男性. 肝性脳 症IV度にて移植前に低体温療法を施行した。父親の左 葉(グラフト重量/標準肝重量比，GV/SV 比51\%)を移 植した。切除された自家肝はほほ全肝が壊死像を呈し ていた。移植後 1 週間の肝生検像では微小胆管周囲に 肝再生像がすでに確認され，移植後 6 力月には自家肝 全体におよぶ良好な肝再生像が観察された。CT スキャ ンにおいては自家肝容積の著明な増加が確認され，GSA シンチでも自家肝への取り込みは急速に増加し，良好 な肝再生の様子が確認された. 移植後 18 力の時点よ り開始された免疫抑制剤の減量とともに, 移植肝は著 明に萎縮し, 移植後 20 力月の時点で免疫抑制剤の中止 が可能となった。

症例 2 は原因不明の 41 歳の女性. 黄㾝から脳症発現 までの期間は約 2 週間。姉の左葉 $(\mathrm{GV} / \mathrm{SV} 35 \%)$ を移 植した。移植後 1 力月の肝生検で微小胆管の増生像が 観察されたものの, その後の肝生検像には著明な変化

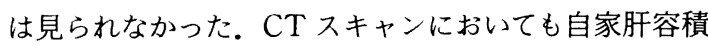
に変化は見られず，完全に社会復帰は果たしているも のの, 移植後 13 力月を経た現在においても有意な肝再 生像は確認されていない。

症例 3 は原因不明の56歳女性. 移植前肝性脳症はIII 度，黄㾝から脳症発現までの期間は約 3 週間．息子の
左葉 $(\mathrm{GV} / \mathrm{SV} 52 \%)$ を移植した。A型から O 型への血 液型不適合肝移植となり, 移植後 6 力月の時点から胆 道系に襄状の拡張像が観察された。以後, 難治性の胆 管炎を繰り返し，移植後11力月敗血症にて死亡した。 CT スキャン上の自家肝容積に変化はみられず，また， 肝生検像によっても自家肝の再生は観察されなかった。

【考察〕通常の全肝あるいは部分肝移植に比べて, APOLT は手技が複雑になるうえ, 肝実質切離時に出 血の見られることが多い.したがって, 劇症肝不全に おいて APOLT が適応になるのは自家肝の再生が期待 できる場合のみと考えてよい.40歳以下の症例や黄疸 から脳症発現までの期間が短いもの, あるいは劇症肝 不全の原因が $\mathrm{A}$ 型や $\mathrm{B}$ 型肝炎ウイルスあるいは薬剤に よる場合には，それ以外の症例に比べて自家肝の再生 は良好であったと報告されている2,3). 今回の症例にお いても，22歳の症例 1 でのみ自家肝の再生が観察され， APOLT の本来の目的である免疫抑制剤の中止が可能 となった。

自家肝の再生を大きく左右する因子として門脈血流 がある. 移植直後では, 大部分を占める壊死組織のた め, 自家肝への血流は低值となる. しかしながら, 肝 再生が進行するとともに血管抵抗が減弱し, 自家肝へ 流入する門脈血は増大し, 自家肝の再生に寄与するも のと考えられる. したがって, 自家肝の再生が不充分 な場合には移植肝への門脈血流を減らし, 自家肝への 門脈血流を増やすような積極的な治療も考慮しなけれ ばならない. その時期や方法については今後の課題で ある。

自家肝に充分な再生が見られた場合, 免疫抑制剤を 中止すれば拒絶反応により移植肝は自然退縮するため, 通常移植肝の摘出は行わない. しかしながら, 血液型 不適合肝移植の場合には約半数の症例で難治性の胆道 系障害が発現すると指摘されており4)，ある程度の自家 肝の機能が確認できた時点で, 胆道系合併症を未然に 防ぐべき移植肝摘出を考慮することも重要である. 今 回の症例 3 においても, 早期に移植肝の摘出を行って いれば，頻回の胆管炎を防止できただけでなく，門脈 血流が増えることによって自家肝の良好な再生が見ら れていたかもしれない.

〔結語〕自家肝の再生が期待できるような, 特に若年 者の劇症肝不全の症例においては APOLT が考慮され るべきである。自家肝再生の経時的観察を目的として 
はCT スキャンによる肝容積の測定と GSA シンチが有 用である。

文 献：1) Gubernatis G, Pichlmayr R, Kemnitz $\mathrm{J}$, et al : Auxiliary partial orthotopic liver transplantation (APOLT) for fulminant hepatic failure : First successful case report. World J Surg 15:660-666, 1991 2) Chenard-Neu M, Boudjema $\mathrm{K}$, Bernuau J, et al : Auxiliary liver transplantation: Regeneration of the native liver and outcome in 30 patients with fulminant hepatic failureAmulticenter European study. Hepatology 23: 1119-1127, 1996 3) Bismuth H, Azoulay D, Samuel D, et al : Auxiliary partial orthotopic liver transplantation for fulminant hepatitis. Ann Surg $224: 712-726, \quad 1996$ 4) Sanchez-Urdazpal L, Batts $\mathrm{K}$, Gores $\mathrm{G}$, et al: Increased bile duct complications in liver transplantation across $\mathrm{ABO}$ barrier. Ann Surg 218:152-158, 1990 5) Petras $\mathrm{S}$, Aurengo A, Le D, et al: Factor analysis in successive hepatobiliary imaging of native and transplant livers. J Nucl Med 37 : 847-851, 1996

\section{S2-2 劇症肝炎に対する生体肝移植}

池上 俊彦 ${ }^{1}$ 三田 篤義 1 , 中澤 勇一 橋倉 泰彦 ${ }^{1}$, 宮川 䓂一 ${ }^{1}$, 川崎 誠治 ${ }^{1}$ ( ${ }^{1}$ 信州大学第 1 外科)

〔目的〕当初小児慢性肝不全疾患に対して開始された 生体肝移植はその後小児急性肝不全疾患へと適応が搪 大され，さらに，成人急性肝不全例に対しても行われ るようになった，今回これまでに当科で劇症肝炎に対 して施行した生体肝移植症例について検討し，さらに retrospective に APOLT の可能性について検討した。

【対象・方法】当科で施行した生体肝移植症例は 106 例のうち LOHF を含む劇症肝炎症例16例(小览12例, 成人 4 例)を対象とした。

[結果]年齢は平均 10.8 歳 ( 5 力月〜36歳)で, 体重 は平均 $30.4 \mathrm{~kg}(7.5 \sim 64 \mathrm{~kg})$ で体格から APOLT 可能な のは $30 \mathrm{~kg}$ 以上の 8 例と考えられた。原因は薬剤性 4 例, B 型肝炎 2 例, Wilson 病 1 例, 不明 9 例であった. 原 疾患の点からは APOLT 可能なのは薬剤性の 4 例およ び原因不明の 9 例で計13例と考えられた。ドナーは親 が14例で，同胞が 2 例であり，1 例が血液型不適合で あった。レシピエントは全例術前 II 度以上脳症を有し 4 例はIV度の昏睡で，全例血漿交換ないし交換輸血を 行った，血槳交換を施行した例では，最少 2 回から最 多43回であり, 総血漿交換量は $1.5 l$ から $136 l$ に及んだ.
発病から移植までの日数は11日から 380 日で100日以上 要した例が 4 例あった。手術では全例全肝を摘出し同 所性にグラフトを移植した。用いた移植片は外側区域 が 4 例, 拡大外側区域が 4 例, 左葉が 8 例でうち 1 例 は尾状葉を含むグラフトであった。術中の門脈一大循 環シャントは 4 例で行い, うち 1 例で体外経路とし, 残り 3 例は一時的門脈大静脈シャントを体内で作成し た。ドナーでは術中術後の輸血はすべて自己血のみで 対処可能であり, 術後合併症は上部消化管潰瘍が 1 例, 術後胃からの食物の排泄障害 1 例であった。レシピエ ントでは人工呼吸器からの離脱が術後 2 日目以降にな るものが多かったが，全例術後は血槳交換は要せず， 神経学的な障害を残さず回復した。1 例が退院後に術 後 8 力月で薬剤性の自己免疫性溶血性貧血が原因で死 亡したが，その他の15例は生存しており累積生存率は 6 力月が $100 \%, 5$ 年が $92 \%$ であり, 全体での 6 力月お よび 5 年生存率 $89 \% ， 85 \%$ に比べ良好であった. 原因 不明の LOHF の 1 例が原因不明の肝硬変となっている.

〔考察〕APOLT は腹腔内の容積, 血管系などの物理 的な問題や原疾患を考慮すると, 年長の小児例あるい は成人例で薬剤が原因か原因不明の例に限ると考えら れ，当科で生体肝移植を施行した劇症肝炎症例のうち retrospective に見て APOLT を考慮しうる可能性のあ るものは 6 例と考えられた。しかし，年長児や成人例 の劇症肝炎に対する生体肝移植自体まだ症例数が少な く，その成績がようやく安定しつつあるところであり， 自己肝に対する門脈血流を温存した状態でグラフトを 生着させるための方策もまだ確立したとは言い難い状 況であり, APOLT の開始は今後の課題と考える.

〔結語〕劇症肝炎に対する生体肝移植は有効な治療法 であると考えられた。

\section{S2-3 自己肝温存部分生体肝移植の評価}

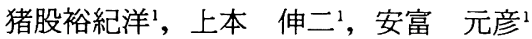
金 一徳 ${ }^{1}$, 高梘 光寿 ${ }^{1}$, 田中 紘一 ${ }^{1}$ ('京都大学移植外科)

自己肝温存同所性部分生体肝移植 (以下 APOLT と 略す)は, 劇症肝不全において, 自己肝の再生を期待す る目的で自己肝を一部残して部分肝移植を行い, 自己 肝の再生が成就された場合には免疫抑制を中止して移 植肝機能を廃絶させ, 一方, 自己肝がそのまま萎縮し てしまう場合には, 通常の肝移植のごとく免役抑制を 終生継続する手技である，我々は，この手技を，元来 の適応以外の異なる理由で，合計26例に利用してきた。 
まず，移植肝のサイズが十分でない場合に自己肝にも 移植直後の代謝需要を一部まかなってもらう，いわゆ る，過小グラフト対策のひとつとして，第二に，代謝 性疾患では，欠損醉素の補充のみが移植肝に期待され， 自己肝自体，欠損酵素以外の機能は正常であることか ら, 万一の移植肝機能廃絶時に残存自己肝機能に当面 の肝機能保持を期待する目的，さらに，血液型不適合 移植の際に，高率で予測される移植肝機能異常時対策 としても用いた。 26 例中，過小グラフト対策として 18 例，代謝疾患に対するもの 5 例， $\mathrm{ABO}$ 不適合移植での 安全機構として 1 例，いわゆる劇症肝不全でのオリジ ナルの適応として 2 例(いずれも小児)であった。過小 グラフトとしての適応中， 2 例の $\mathrm{HB}$ 劇症肝炎が含ま れたが，他は慢性肝疾患またはその急性憎悪であった。 自己肝への門脈血流は, 代謝疾患のうち 2 例, 劇症肝 不全に対する適応の 2 例，および過小グラフトに対し てのうち初期のもの 3 例では温存したが，それ以外の 症例では完全離断し, 門脈血流は全て移植肝へ流入さ せた。また，代謝疾患の 1 例では，自己肝が，移植肝 の拒絶反応時に再生増大したままとなって移植前の症 状が再発し, 拒絶反応の沈静後も移植肝機能の再生が 不良であったため，二次的に自己肝への門脈を離断し
て移植肝の再生をはかり有効であった。移植肝として は，過小グラフトへの適応症例中 1 例でドナーの右葉 を用いた。過小グラフト症例中， 2 例で，移植肝の増 大を待って自己肝の全摘出を二次的に施行した。

APOLT 全体の成績は, 過小グラフトへの適応では, 18 例中 10 例生存 $(56.6 \%)$, 代謝疾患は 5 例とも生存, 劇症肝不全への適応では 2 例とも死亡した，血液型不 適合移植では，移植肝が強い拒絶反応を呈して機能不 全に陥っているが, 残存自己肝がかろうじて機能して おり，再移植待機中である，劇症肝不全への適応に限 ると，再生を期待した 2 例では早期に患者の死亡また は移植肝機能不全に陥り, 初期の目的を評価できなかっ た。 また，過小グラフトでの適応症例中でも，劇症肝 炎症例での自己肝再生は観察されず, 逆に, 劇症肝不 全や慢性疾患の急性憎悪症例など，非常に自己肝機能 が障害されていた症例での生存率が特に不良であった。 過小グラフトでの生存例ではいずれも移植肝の増大が みられ，自己肝は萎縮していく傾向がみられた。

我々の経験では, 劇症肝不全に扔ける APOLT は症 例も少なく評価が困難であったが，過小グラフトでの 適応では, 当然ながら, 自己肝機能が極度に障害され た症例では成績が不良であった。

\section{シンポジウム（3）肝移植後のウイルス肝炎再発と光の対策}

\section{S3-1 成人ウイルス肝资に対する肝移植}

清水 保延 ${ }^{1}$, 松波 英寿 ${ }^{1}$, 清水 明 ${ }^{1}$

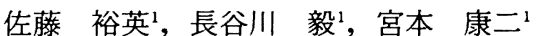
清水 幸雄 ${ }^{1}$, 瀬戸口 誠1, 由良 二郎 ${ }^{1}$ 稲田 潔1, 松波 英一', 中村 憲昭 ${ }^{2}$ 大屋 英樹 ${ }^{2}$ ，赤井 昭文 ${ }^{2}$, 村井 敏博 ${ }^{2}$ 山北 宜由 ${ }^{2}$

('松波総合病院外科, ${ }^{2}$ 同 内科)

索引用語：Hepatitis C, Hepatitis B, Liver Transplantation

我が国ではB 型およびC 型のウイルス肝炎による肝 硬変のため, 肝不全, 肝性脳症, 繰り返す胃食道動脈 瘤出血を来したり，これに肝癌を併発する患者もあり， 移植以外の治療法では対処できない患者が多数存在す る。これらに対する肝移植は, 原疾患がウイルス肝炎 であるため，その適応と再発への対処が問題である. これに関し，自験例をもとに検討した。

対象として Australiaの Queensland Liver Trans- plant Service(以下 QLTS)において脳死肝移植を受け, 当院で経過観察中の成人患者31例と, 当院において生 体肝移植を施行した成人患者 4 例の合計 35 例とした。 35 例中術前に $\mathrm{B}$ 型肝炎の抗原陽性患者は 1 例, 抗体 のみ陽性患者は 7 例であり, C 型肝炎は術前 RNA 陽 性が確認された患者は 5 例，抗体のみ陽性の患者が 4 例であった。成人脳死肝移植症例 31 例中の 5 例が死亡， 生体肝移植症例 4 例はいずれも健在である. 死亡症例 5 例中でウイルス肝炎が関係した患者は 1 例のみで, 当院での経過観察患者においては, 生存率は他疾患と 遜色なかった。

このうちB型肝炎に関しては, 術前に HBs 抗原陽性 ( $\mathrm{HBe}$ 抗原陰性)であった患者が術後 $\mathrm{HBe}$ 抗原陽性と なり，B型肝炎再発による劇症化で術後 7 力月に死亡 した。これ以外の抗体のみ陽性の 7 例は, 現在まで全 例 B型肝炎抗原陰性で, 再発なく生存中である.

C 型肝炎に関しては術前から抗体陽性であった 9 例 中, 術前に HCV-RNA 陽性を証明しえた 5 例と, 術 
前には抗体検査のみが実施でき陽性であった 1 例が, 術後の現在 HCV-RNA 陽性である.いずれも生存中 で, 肝硬変に至った患者はいないが, 術後 HCV-RNA 陽性の 6 例のうち 1 例でウイルス量の増加とともにC 型肝炎に伴うと考えられるネフローゼ症候群を呈し， Dipyridamole を投与するとともに, Ribavirin および Interferon にて加療中である.この症例は投与開始後 に, 肝機能の改善およびウイルス量の減少をみ, 現在 まで拒絶反応の発症を認めていない.また他の $\mathrm{HCV}$ -RNA 陽性症例におけるウイルス量の推移は, 変動は あるが経過とともにウイルス量の増加を認めた。

ウイルス肝炎に伴い, 肝癌を合併した患者を 4 例経 験した。この 4 例のうち， 1 例は B 型肝炎の抗原陽性 患者, 3 例はC 型肝炎 RNA 陽性患者であった。いずれ も TAE, PEITによる加療を繰り返したが軽快せず, 肝外病変がないことを確認し, 移植適応と判断し, 脳 死移植を受けるためQLTS に紹介した。移植適応と判 断した段階での肝癌は最大径 $30 \mathrm{~mm}$ 以下で, 個数は 2 〜 5 個であった。これらの患者は脳死肝移植を受けた 時点でも肝外には病変は認めず, 肝移植手術が行われ た. 移植時における肝癌の最大径は $17 \sim 35 \mathrm{~mm}$, 個数は 小さいものも含め $2 \sim 17$ 個であった. 再発に関しては, $\mathrm{B}$ 型肝炎の劇症化で失った症例も剖検時に肝癌再発は 認めないことを確認でき, その他の現在生存している 症例も, 移植後に AFP 值が正常範囲となり, 現在も正 常範囲に保てており, CT 等による経過観察にて移植後 7 力月〜 2 年 7 力月の現在まで再発兆候は認めていな い.

B 型肝炎患者の再発死亡およびC 型肝炎患者の経過 から見て, ウイルス肝炎患者には, 再発, 劇症化, 肝 硬変への移行を常に念頭にいれて考える必要性があり, 現時点では適応を限定や対処が必要である。現在はま だ症例数も少なく, 経過時間も短いため対策を模索中 であるが，B型肝炎に関しては，ウイルスが存在する と移植後の再発率が高いとされ(1), Lamivudine, HBIG の投与が再発防止に有効との報告もある21. しか し現時点では $\mathrm{HBe}-\mathrm{Ag}(+)$ および $\mathrm{DNA}(+)$ 症例は除 外している施設が多い. 当院では抗原陰性症例でも, 術後の再発を考慮してLamivudineおよびHB-globurin を投与した症例もある。

C 型肝炎に関しては経過が長く, B 型肝炎に比して 重症化の頻度も低いが, 術前からウイルス陽性患者の 全例で, 血清学的再発をみており, そのなかには肝障 害やその他の合併症が出現した症例を経験した。肝移
植後の症例に対するInterferon の投与に慎重な意見も あるが3)，Ribavirin および Interferon の投与が有効と の報告もみられる ${ }^{4,5)}$. 当院の症例でも現在まで良好な 経過をみており, 症状を呈する症例では, Ribavirin お よび Interferon の投与を考慮する必要があると考える. 適応に関しては脳死肝移植と生体肝移植では異なる が, どちらにおいても Lamivudine や Ribavirin の登場 によりすべてを禁ずるのではなく, 以前よりは適応を 広げていけると考える。

〔まとめ〕ウイルス肝炎においても，再発に対する術 前術後の対策と注意深い観察により良好な結果を期待 しうると考える.

文 献：1）谷川久一：肝移植適応基準. 医学のあゆ み $166: 841-842,1993$ 2) 野口和典, 谷川久一： B 型肝炎ウイルスによる肝障害に対する肝移植：現状 と問題点. 肝胆膵 $33(1): 43-49,1996$ 3) Feray C, Samuel D, Gigou M, et al: An open trial of interferon alfa recombinant for hepatitis $\mathrm{C}$ after liver transplantation: antiviral effects and risk of rejection. Hepatolgy $22: 1084-1089,1995$ 4) 浜 村啓介, 小俣政男：C型肝炎ウイルスによる肝障害に 対する肝移植: 現状と問題点. 肝胆膵 33(1): 51-54, 1996 5) Bizollon T, Ducerf C, Trepo C : New approaches to the treatment of hepatitis $C$ virus infection after liver transplantation using ribavirin. J Hepatol 23 Suppl 2:22-25, 1995

\section{S3-2 移植後の急速進展型 C 型肝资と关の対策} 福本 巧 ${ }^{1}$, 具 英成 ${ }^{1}$, 黒田 嘉和 ${ }^{1}$ (1神戸大学第 1 外科)

索引用語： C 型肝炎, 肝移植術, リバビリン

〔目的〕C型肝炎ウイルス陽性者の肝移植後には高率 な移植肝再感染が報告されているが肝病変の進行は B 型肝炎に比し一般的に緩徐で 5 年生存率も非感染性疾 患に比べ著明な差を認めていない1). しかし数\%と低率 であるが移植後, 数力月から数年以内の短期間に肝硬 変を呈する急速進展型が存在し, その病態の解明と対 策が急務となっている21. そこで今回, 血中 HCV-RNA が異常高值を示し, 2 回の再移植が必要となった 1 例 とGOT が移植後 7 カ月目に突然異常高值を示し, リバ ビリン・IFN が有効であった 1 例の 2 つの異なる病像 を示した急速進展型 C 型肝炎の自験 2 例の臨床経過を 報告する。

〔症例 1〕43歳男性, 1993年12月に HCV (genotype 1b)肝硬変のため Berlin Virchow 病院にて同所性肝移 
植術を受けた。サイクロスポリン，アザチオプリン， プレドニンによる免疫抑制療法を受けていたが術後 2 週間目の肝生検で HCV の再感染及び急性拒絶を認め, サイクロスポリンをFK506に変更した。 その後 GOT, $\mathrm{GPT}$ は $100 \mathrm{U} / l$ 前後, $\mathrm{T}$-bil は $5 \mathrm{mg} / \mathrm{d} l$ 前後に低下し たが, 術後 1 力月の血中 HCV-RNA は $6.2 \times 10^{6}$ $\mathrm{copies} / \mathrm{m} l$ と高值で推移した，以後肝機能は著変なく 経過していたが血中 HCV-RNA の低下とともに，移植 後10力月目の肝生検にて高度の繊維化を伴う肝硬変と 診断し，1994年12月に再度肝移植術を施行した。第 2 回目の移植後は FK506を主剤とする免疫抑制を行った が 1 力月目には前回と同様に HCV の再感染及び急性拒 絶を認め, 血中 HCV-RNA も最高値 $3.0 \times 10^{6} \mathrm{copies/}$ $\mathrm{m} l$ に達した。その頃より $30 \mathrm{mg} / \mathrm{d} l$ に達する持続的な高 ビリルビン血症を来し，10力月後の肝生検にて肝硬変 が確認され，1995年12月に 3 回目の肝移植術を施行し た．前回同様 FK506を中心とした免役抑制を行ってい たが術後 2 週間で血中 HCV-RNA は4 .0 $0 \times 10^{6} \mathrm{copies/}$ $\mathrm{m} l$ に達し,リバビリン $(800 \mathrm{mg} / \mathrm{day})$ の単剤投与を開始 した．投与後10力月間は GOT，GPT 及び T-bil は正 常值にとどまり血中 HCV-RNA も $1.5 \times 10^{6} \mathrm{copies} / \mathrm{m} l$ を越えていない(図 1).

【症例 2 〕 46歳男性, 1996年 4 月に HCV (genotype 1b) 肝硬変のため Berlin にて同所性肝移植術を受けた. サイクロスポリン，アザチオプリン，プレドニンの免 疫抑制剂により術後経過は順調で同年 6 月に帰日した。 同年 7 月より突然 GOT $(948 \mathrm{IU} / l) ， \mathrm{GPT}$ の上昇を認 め, 肝生検により C 型肝炎の再燃を疑い，免疫抑制郕 を減量したが GOT，GPT の上昇は持続した。再度施 行した肝生検では既に広範な bridging fibrosis, 散在 性の肝細胞壊死を伴う慢性活動性肝炎の像を呈し急速 進展型のC型肝炎再然と判断した。この時点で肝病変 の進行が急速なこと，日本では再移植が困難なことな どを考虑し，リバビリン及び IFN の併用療法を勧めた が患者は移植前の IFN 療法が無効であったことなどよ り1997年 2 月よりリバビリン $(800 \mathrm{mg} /$ day $)$ の単剤投与 を開始した。しかし 4 力月後も GOT, GPT 及び HCV -RNA 量の改善を認めなかったため1997年 7 月よりリ バビリンと IFN の併用療法に変更した. 1997年 8 月に は HCV-RNA は陰性化し GOT, GPT もほほ正常化 した。中程度の溶血性貧血のため1997年11月より IFN の単剤療法に切り替えたが， 2 週間後 GOT, GPT は $100 \mathrm{IU} / l$ 前後まで上昇したため再度リバビリンを投与し た。その結果 GOT, GPT は再び正常化し, 現在に
至っている.

〔考察〕症例 1 では GOT などの肝酵素は中程度の上 昇に留まったが血中 HCV-RNA は 3 回の移植後とも異 常高值を示した。また第 1 回および第 2 回移植後は 1 年以内に急速な肝硬変への進展を認め, 明らかに通常 のC型肝炎陽性者の術後経過茾4) とは異なっており，免 疫抑制剂の免疫応答に対する特別な修飾が推測された。 また症例 2 は再発 B 型肝炎に類似した病態を示し, GOT などの肝酵素の異常高値が持続し，症例 1 とは異 なった急速進展型 C 型肝炎の病像を呈した。本例では リバビリン・IFN が有効で血液生化学上, 肝炎の長期 間の沈静化が達成されておりリバビリン・IFN 併用療 法の有用性が強く示唆された．以上のように免疫抑制 下では肝移植後数力月から数年以内と短期間に肝硬変 に進展する急速進展型のC 型肝炎の再燃形式があり, 低率ではあるが HCV 陽性例では本症を念頭においた術 後管理が重要になると考えられた。また少数ではある が自験例の経験からリバビリン・IFN 併用療法は genotype 1b, IFN 無効例でも積極的に試みるべき療法 と思われた。

文 献：1) Feray C, Gigou M, Samuel D, et at : The course of hepatitis $C$ virus infection after liver transplantation. Hepatology $20: 1137-1143,1994$ 2) Berg T, Hopf U, Bechstein WO, et al : Pretransplant virological markers hepatitis $\mathrm{C}$ viurs genotype and viremia level are not helpful in predicting individual outcome after orthotopic liver transplantation. Transplantation $66: 225-8,1998$ 3) Chazouilleres $\mathrm{O}, \mathrm{Kim} \mathrm{M}$, Combs $\mathrm{C}$, et al: Quantitation of hepatitis C virus RNA in liver transplant recipients. Gastroenterology 106 : 994-999, 1994 4) Fukumoto T, Berg T, Ku Y, et al:Viral dynamics of hepatitis $\mathrm{C}$ early after orthotopic liver transplantation: evidence for rapid turnover of serum virions. Hepatology 24: $1351-1354,1996$ 

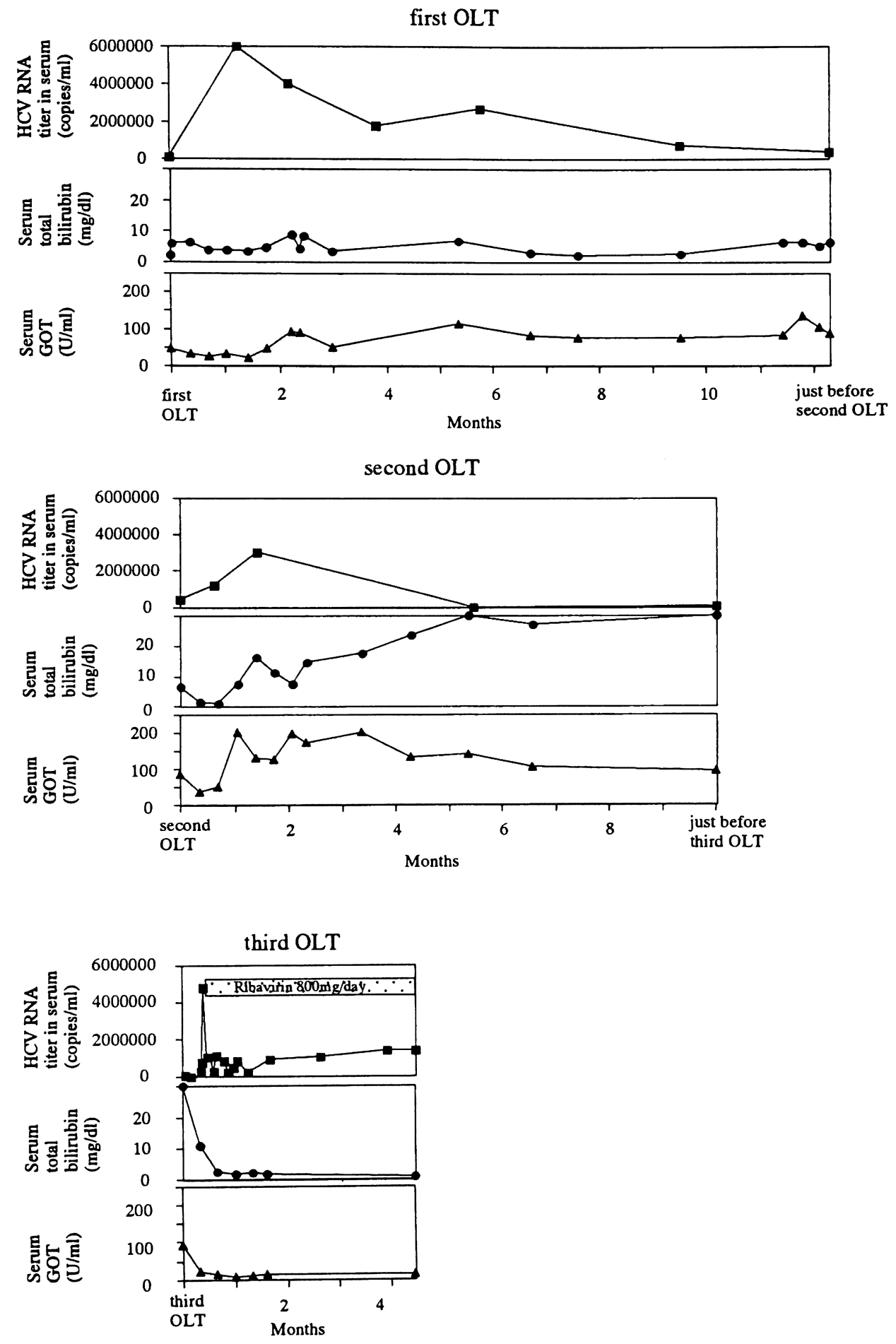

図 1 Serial changes in GOT, serum total bilirubin and HCV-RNA levels after first, second and third transplantation. 
S3-3 肝炎ウイルス陽性例に対する生体部分肝移植 針原康 ${ }^{1}$, 幕内 雅敏 ${ }^{1}$, 高山 忠利 ${ }^{1}$ 潐田 敬一 ${ }^{1}$, 平田 勝 ${ }^{1}$, 北 嘉昭 ${ }^{1}$ 佐野 圭二1, 久富 伸哉 ${ }^{1}$, 三浦 泰朗 谷合 信彦1, 日下 浩二1，回 愛民1 青木 琢 ${ }^{1}$, 平井 一郎 ${ }^{1}$, 松倉 聡 長谷川 潔'，前間 篤 ${ }^{1}$, 阪本 良弘 ${ }^{1}$ 小林 隆 ${ }^{1}$, 緑川 泰 ${ }^{1}$, 加藤 正人 ${ }^{1}$ 高津 光 ${ }^{1}$, 伊東 充宏 ${ }^{1}$, 水田 耕一 1 田中 秀明 ${ }^{1}$, 吉野 浩之 ${ }^{1}$, 河原崎秀雄 ${ }^{1}$

橋都 浩平

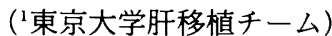

〔はじめに〕 HBV 陽性肝硬変症例は，移植肝への再 感染が高率なことと再感染後の肝病変の進行が急速な ことより，一時期肝移植適応の相対的禁忌と考えられ ていた。しかしながら近年高 HBs 抗体価ガンマグロブ リン (HBIG) や抗ウイルス剤の使用により，移植肝への 再感染が効果的に予防できるようになり，適応が見直 されている。一方, HCV 陽性肝硬変症例は，移植肝へ の再感染は高率に認められるものの, 再感染後の肝病 変の進行は比較的緩徐なため, 肝移植の良い適応と考 えられている，当院で生体部分肝移植を施行した肝炎 ウイルス陽性症例と，海外で肝移植を受けた HBV 陽性 肝硬変症例について，その肝炎ウイルス再感染予防対 策と経過について検討したので報告する.

【対象〕東京大学では1996年 1 月から1999年 3 月まで の間に小児例38例，成人例18例(18歳以上)の計56例の 生体部分肝移植を実施した。この中で肝炎ウイルスが 関与した 4 例と HBV 陽性肝硬変にて海外で脳死肝移 植を受けた 1 例の計 5 例について検討した。（症例 1) 50 歳男性肝硬変, $\operatorname{HBsAg}(+), \operatorname{HBeAg}(-)$, 息子を ドナーとして生体部分肝移植施行, 移植前よりラミブ ジン $150 \mathrm{mg}$ /日を投与, また術中から術後に HBIG を投 与した。移植後11力月経過, 肝機能正常で, HBV 再 感染 $(-)$. 症例 2) 58歳男性肝硬変, $\operatorname{HBsAg}(+)$, $\operatorname{HBeAg}(-), \operatorname{HCVAb}(+), \mathrm{HCV}-\mathrm{RNA}(+)$, 息子 をドナーとして生体部分肝移植施行, 移植前よりラミ ブジン $150 \mathrm{mg}$ /日を投与，また術中から術後に HBIG を 投与した. 移植後 10 力月経過, HBV 再感染 $($-)だが, 血中HCVウイルス量は増加している。（症例 3）44歳 男性 HCV に上る肝硬変, 移植後 1 力月, 経過観察中. （症例 4）25歳男性HBVによる亜急性劇症肝炎, 兄 をドナーとした生体部分肝移植施行，ただし移植時に は既に HBsAg(-)，HBsAb(+)であった，HBIG を
術後一時的に投与, HBV再感染 $(-)$. （症例 5 ） 50 歳男性肝硬変, $\operatorname{HBsAg}(+), \operatorname{HBeAg}(+)$, 海外にて 脳死ドナー肝移植施行，現在に至るまで HBIG を継続 投与, 移植後 4 年, 肝機能正常で HBV 再感染 (-).

〔結論〕HBV 陽性肝硬变症例に対しては可能ならば 移植前にラミブジンを 4 週間以上投与し，ウイルス量 を十分に減少させた上で，肝移植を行い，移植後は $\mathrm{HBIG}$ を移植後 3 力月間は $500 \mathrm{IU} / l$ 以上, 3 力月以降 は250IU/lに保つように適宜投与して再感染予防につと めるプロトコールを採用している。一方， HCV 陽性肝 硬変症例に対しては現在のところ有効な再感染予防法 はないので，他の疾患と同様に肝移植を行い，HCV ウ イルス量と肝機能の推移を経過観察する方針である. 肝障害が認められた場合には, 必要ならば肝生検を行 い, HCV 再感染によるものと診断されれば, インター フェロンとリバビリンを投与する準備をしている.

\section{S3-4 生体肝移植における B 型肝资ウイルス対策}

上本 伸二 ${ }^{1}$, 猪股裕紀洋 ${ }^{2}$, 田中 紘一 ${ }^{1,2}$ ( ${ }^{1}$ 京都大学移植医療部, ${ }^{2}$ 同 移植外科)

索引用語：B型肝炎ウイルス, 生体肝移植, ラミブ ジン

〔はじめに〕ラミブジンの使用により，欧米における $\mathrm{B}$ 型肝硬変に対する肝移植の成績は飛躍的に向上して きた ${ }^{1)}$ ，一方，わが国における生体肝移植は成人への適 応拡大に伴い，B型肝硬変患者が治療対象となってき た。肝移植後の de-novo B 型肝炎発症は古くから報告 されていたが，その大部分が $\mathrm{HBc}$ 抗体陽性ドナーから の $\mathrm{B}$ 型肝炎ウイルスの伝播によるものであることが最 近解明されてきた 2 (2). わが国における高いB 型肝炎の 䍜患率を考えると， $\mathrm{HBc}$ 抗体陽性ドナーからの肝移植 における対策は今後の脳死肝移植においても重要な問 題である。

〔 $\mathrm{B}$ 型肝硬变〕肝移植後の $\mathrm{B}$ 型肝炎再発防止のため に，1998年11月より，ラミブジンと抗 B 型肝炎免役グ ロブリン $(\mathrm{HBIG})$ 併用療法を開始した。ラミブジンは 150 $\mathrm{mg}$ /日を移植前 8 週間と術後に投与, HBIG は術中無 肝期に $10,000 \mathrm{IU}$ ，術後 4 日間 $10,000 \mathrm{IU} /$ 日，その後は 血中 $\mathrm{HBs}$ 抗体を $500 \mathrm{IU} / \mathrm{l}$ 以上を維持する投与をプロト コールとした．現在までに経験した 5 例はすべて男性 (38歳一50歳)で， 2 例が肝癌を合併していた。 Table 1 はラミブジン投与前後, 移植後の B 型肝炎ウイルスに 対するセロロジーの変化を示す．2 例は $\mathrm{HBe}$ 抗原，血 中 HBV-DNA が陽性であったが，術前 8 週間のラミブ 
Table 1 Changes in serology for hepatitis B virus following living donor liver transplantation using combination lamivudine and hepatitis B immune globulin

\begin{tabular}{|c|c|c|c|c|c|c|c|c|}
\hline \multirow[t]{2}{*}{ Patient } & \multicolumn{2}{|c|}{ pretreatment } & \multicolumn{4}{|c|}{ pretransplant } & \multirow{2}{*}{$\frac{\text { posttransplant }}{\mathrm{HBsAg}}$} & \multirow{2}{*}{$\begin{array}{l}\text { Follow-up period } \\
\text { (months) }\end{array}$} \\
\hline & $\mathrm{HBeAg}$ & HBV-DNA & Lamivudine & $\mathrm{HBeAg}$ & HBV-DNA & HBsAg & & \\
\hline 1 & $(+)$ & $(+)$ & $(+)$ & $(-)$ & $(-)$ & $(+)$ & $(-)$ & 7 \\
\hline 2 & $(-)$ & $(+)$ & $(+)$ & $(-)$ & $(-)$ & $(+)$ & $(-)$ & 5 \\
\hline 3 & $(-)$ & $(-)$ & $(-)$ & $(-)$ & $(-)$ & $(+)$ & $(-)$ & 3 \\
\hline 4 & $(-)$ & $(-)$ & $(-)$ & $(-)$ & $(-)$ & $(+)$ & $(-)$ & 2 \\
\hline 5 & $(+)$ & $(+)$ & $(+)$ & $(-)$ & $(-)$ & $(+)$ & $(-)$ & 2 \\
\hline
\end{tabular}

ジン投与中に $\mathrm{HBe}$ 抗原陰性・HBe 抗体陽性とセロコ ンバージョンを来し, 血中 HBV-DNA も陰性となった. 1 例は 3 年前のインターフェロン治療により $\mathrm{HBe}$ 抗原 陰性・HBe 抗体陽性となりウイルスの $70 \%$ が pre-core mutant となっていたが, 血中 HBV-DNA は陽性で あった。術前 2 週間のラミブジン投与中に血中 HBV -DNA は陰性化した. 肝摘出直後の HBIG 投与によ $\eta, 5$ 例とも移植翌日から $\mathrm{HBs}$ 抗原陰性・HBs 抗体 陽性となり, その後も HBs 抗原陰性が移植後 2 力月か ら 7 カ月のフォローアップ期間中持続している.

〔HBc 抗体陽性ドナーからの肝移植〕 $\mathrm{HBc}$ 抗体陽性 の健常者の肝臓には B 型肝炎ウイルスが高率に存在し, 肝移植によってレシピエントにウイルスの伝播が生じ ることが判明してきた ${ }^{3)}$. したがって，基本的に $\mathrm{HBc}$ 抗 体陽性者は生体肝移植のドナーとして不適切でありド ナ一候補者から除外すべきであるが，日本人における 高い $\mathrm{HBc}$ 抗体陽性率 $(10 \%-30 \%)$ を考慮すると， $\mathrm{HBc}$ 抗体陽性者をドナーとして完全に除外することは 現実的ではなく,このことは脳死肝移植においても避 けては通れない問題である. 実際，1995年からは HBc 抗体陽性者を生体肝移植ドナーから除外する方針とし たが，他に適切なドナー候補者がいないことから 26 例 (9.5\%)が $\mathrm{HBc}$ 抗体陽性者からの肝移植であった. 26 例中 24 例の $\mathrm{HBc}$ 抗体陽性ドナーの肝臓から B 型肝炎ウ イルス DNA が nested PCR 法で検出された。検出さ れなかった 2 例は $\mathrm{HBc}$ 抗体価がそれぞれ $52.7 \% \mathrm{INH，}$ $51.5 \% \mathrm{INH}$ のボーダーラインの症例であった．血清か らの DNA は26例すべて陰性であった。

$\mathrm{HBc}$ 抗体陽性ドナーからの生体肝移植においては, レシピエントのB型肝炎発症予防の目的のために, $\mathrm{HBIG}$ を無肝期に200IU $/ \mathrm{kg}$, 術後 $1-4$ 日間に200 $\mathrm{IU} / \mathrm{kg}$ /日の投与を行い, 以後は血中 HBs 抗体価を 200 $\mathrm{IU} / l$ 以上維持するプロトコールを行った.レシピエン トが $\mathrm{B}$ 型肝炎関連疾患 (劇症肝炎, 肝硬変) 症例と移植
後早期に B 型肝炎以外で死亡した症例を除く13症例に おいて上記プロトコールの有効性を検討した. フォロー アップ期間は平均15力月（ 6 力月一 4 年）である．13例 中 9 例は最長フォローアップの症例を含めて HBs 抗原 陰性が持続しているが，4 例は移植後12力月，12力月， 15力月，21力月にそれぞれ HBs 抗原陽性となった． 2 例はノンコンプライアンスのため HBIG 投与が行われ なかった 3 力月後と 6 力月後に HBs 抗原陽性となった が，2 例は HBIG 投与プロトコール継続中に HBs 抗原 陽性となった。 3 例は肝炎を発症しておらず経過観察 中であるが，1例は B 型肝炎発症を来したためラミブ ジン投与を開始した。現在, 肝炎は鎮静化し, ラミブ ジンと HBIG 併用療法継続下に HBs 抗原陰性が持続 している.

〔考察〕フォローアップ期間は短いものの, ラミブジ ンと HBIG 併用療法による肝移植後のB 型肝炎再発阻 止効果は期待できる治療法であり, 今後の成人間生体 肝移植の適応疾患の拡大に寄与するものと思われる. $\mathrm{HBc}$ 抗体陽性ドナーからの肝移植では B 型肝炎ウイル スのレシピエントの伝播による B 型肝炎発症予防対策 が重要である. HBIG 投与プロトコールは完全ではな く, 肝炎発症例にはラミブジン投与が必要と考えられ る.

文 献：1) Markowitz JS, Martin P, Conrad AJ, et al: Prophylaxis against hepatitis $B$ recurrence following liver transplantation using combination lamivudine and hepatitis B immune globulin. Hepatology 28:585-589, 1998 2) Dickson RC, Everhart JE, Lake JR, et al: Transmission of hepatitis $B$ by transplantation of livers from donors positive for antibody to hepatitis B core antigen. Gastroenterology 113:1668-1674, 1997 3) Uemoto S, Sugiyama K, Marusawa $H$, et al. Transmission of hepatitis B virus from hepatitis B 
core antibody-positive donors in living related liver transplants. Transplantation $65: 494-499,1998$

\section{S3-5 B 型肝资ウイルス，特にラミブジン耐性株に対} する新たなウイルス同

Suzane Kioko Ono-Nita ${ }^{1}$, 加藤 直也 $^{1}$ 白鳥 康史 ${ }^{1}$, 小俣 政男 ${ }^{1}$

('東京大学消化器内科)

索引用語: 逆転写酵素阻害剤, YMDD motif, reverse transcriptase

〔目的〕B型肝炎ウイルス (HBV)に対し逆転写酵素 阻害剤である lamivudine (3TC) は強い抗ウイルス活性 を有する，最近， lamivudine の耐性株の出現が報告さ れ，治療上の重大な問題になっている．われわれは全 長 HBV DNA をヒト肝癌細胞に transfection し複製す る系を確立し，DNA polymerase の reverse transcriptase 活性中心である YMDD motif における1ア ミノ酸変異が lamivudine の耐性獲得に必要十分である ことを報告した ${ }^{1)}$ 。ここでは，野生型 HBV，及び lamivudine 而性 HBV に対する新たな逆転写酵素阻害 剤を用いた治療につき基礎的な検討を行った.

〔方法〕 HBe 抗原陽性患者血清より long-PCR 法に より $3.2 \mathrm{~kb}$ の全長 HBV DNA を増幅し, 野生株を cloning した. lamivudine 而性株は野生株の YMDD motif $の \operatorname{Met}(\mathrm{M})$ を PCR-mediated mutagenesis によ りそれぞれ lle(l)または $\mathrm{Val}(\mathrm{V})$ 一置換する変異を導入 し，作成した。これら cloned HBV DNA をヒト肝癌 細胞 Huh7に transfection し, Southern blot hybridizationにより HBV の複製につき解析した。薬凧感受 性は培養液に lamivudine (Glaxo), adefovir(PMEA) (Gilead Sciences), lobucavir(Bristol Meyers Squid), penciclover(Smith Kline Beecham), nevirapine (Boehringer lngelheim) を加え解析した。

〔成績〕逆転写醭素阻害剤の効果は, HBV DNA の single-stranded band(複製中間体)を用いて解析した (Fig. 1). Lamivudine, adefovir, lobucavir 存在下 では，野生株の複製中間体は消失したが， penciclovir と nevirapine ではこれら複製中間体は減弱しなかった。 Lamivudine 而性株に adefovir 及び lobucavir を作用 させ, lamivudine 而性株が adefovir と lobucavir に 感受性であることを見出した ${ }^{2)}$. Table 1 は8.7 $\mu \mathrm{M}$ の各 逆転写醅素阻害剤存在下での HBV の複製につきまとめ たものである. $8.7 \mu \mathrm{M}$ は野生株 HBVに対する lamivudine の IC 90 の值である。 また同じ濃度で用い た場合, adefovir は lobucavir より強い抗ウイルス効 果を有した. Lamivudine 而性株は野生株に比し，より adefovir, lobucavir 低抗性であり, 野生株より高濃度 の adefovir, lobucavir 投与が必要な可能性がある.

\section{Wild type}

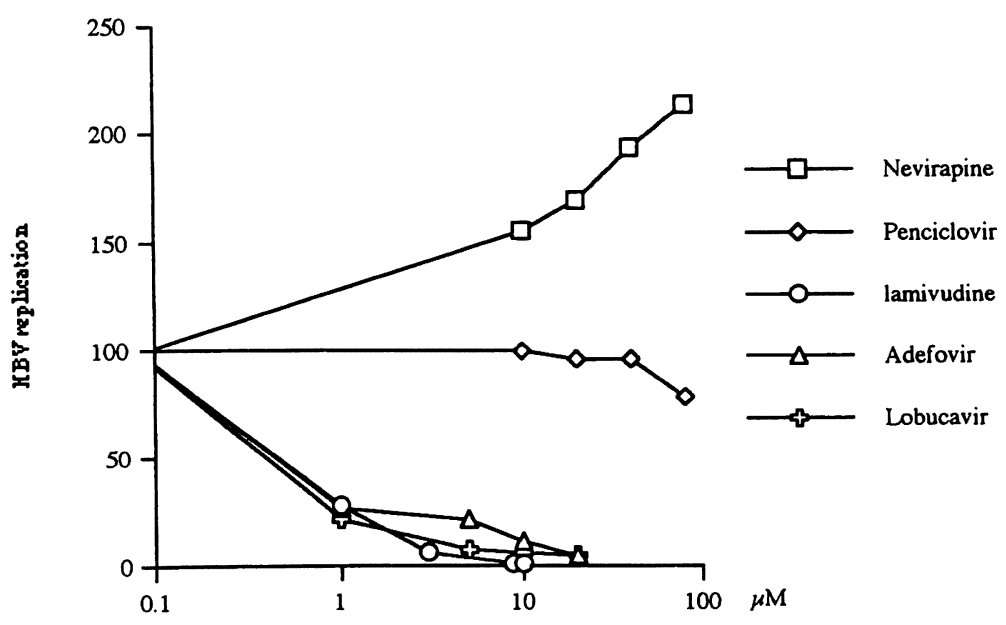

Fig. 1 Drug inhibition curves of wild type $\mathrm{HBV}$ transfected into $\mathrm{HuH}-7$ cells treated with indicated concentrations of nevirapine, penciclovir, lamivudine, adefovir and lobucavir. 
Table 1 Replication of wild type and lamivudine-resistant mutants of $\mathrm{HBV}$ under treatment with antivirals at a concentration of $8.7 \mu \mathrm{M}$.

\begin{tabular}{lcrrc}
\hline & Wild type & M552I & M552V & L528M/M552V \\
\cline { 2 - 5 } No treatment & $100 \%$ & $100 \%$ & $100 \%$ & $100 \%$ \\
Lamivudine & $17 \%$ & $166 \%$ & $88 \%$ & $85 \%$ \\
Lobucavir & $20 \%$ & $36 \%$ & $48 \%$ & $59 \%$ \\
Adefovir & $13 \%$ & $21 \%$ & $31 \%$ & $43 \%$ \\
Penciclovir & $94 \%$ & $171 \%$ & $103 \%$ & $88 \%$ \\
Nevirapine & $170 \%$ & $164 \%$ & $153 \%$ & $109 \%$ \\
\hline
\end{tabular}

〔結論〕Lamivudine 耐性株の高い発生率が報告さ れ, lamivudine 単独療治では B 型肝炎の根治には, 不 十分であると思われる. 有効な B 型肝炎治療には, lamivudine 耐性 HBV 出現を防止することが必要であ る. Lamivudine 耐性株は adefovir と lobucavir に感 受性があると考えられるため, lamivudine と adefovir もしくは lobucavir の併用療法により lamivudine 而性 株出現を防止しうる可能性が示唆された。
文 献：1) Ono-Nita SK, Kato N, Shiratori Y, Masaki $\mathrm{T}$, Lan $\mathrm{K}-\mathrm{H}$, et al: YMDD Motif in Hepatitis B Virus DNA Polymerase lnfluences on Replication and Lamivudine Resistance: A Study by In Vitro Full-Length Viral DNA Transfection. Hepatology 29:939-945, 1999 2) Ono-Nita, Kato N, Shiratori Y, Lan K-H, Yoshida H, et al: Susceptibility of lamivudine-resistant hepatitis $B$ virus to other reverse transcriptase inhibitors. J Clin lnvest $103: 1635-1640,1999$

\section{シンポジウム（4） ハイオ人工肝開発の現況と問題点}

\section{S4-1 人工肝臓に望まれる機能とその現状}

蒲原 行雄 ${ }^{1}$, 宮本 俊吾 ${ }^{1}$, 川添 康 $^{1}$

江口晋 ${ }^{1}$, 川下 雄丈 ${ }^{1}$, 東 尚 ${ }^{1}$

藤岡ひかる ${ }^{1}$, 古井純一郎 ${ }^{1}$, 兼松 隆之 ${ }^{1}$

Kyung-suk Suh ${ }^{2}$, Jacek Rozga ${ }^{2}$

Achilles A. Demetriou ${ }^{2}$

( ${ }^{1}$ 長崎大学第 2 外科, ${ }^{2}$ Department of Surgery, Cedars-Sinai Medical Center)

バイオ人工肝臓に肝細胞を用いる目的は，機械的に 代行できない肝特異的機能を補助することにある。そ の機能とは，1）末知の物質を含む有害物質の除去，2） 肝由来タンパクの供給，3）傷害肝の再生や機能回復の 促進，4）長期にわたる生命維持である.われわれは, これまでに microcarrier 上で培養した初代肝細胞を hollow fiber カラムの膜外スペースに充填した人工肝 臓を作製し，その効果を検討してきた。

〔検討 1] ブ夕急性虚血性肝不全モデルを用い人工肝 蔵の治療効果を検討した，肝不全導入後 6 時間目から 4 時間, 人工肝臓治療を行う治療群と体外循環のみの 対照群を比較検討した。治療群では, 頭蓋内圧の上昇
抑制, 血中アンモニアの良好な除去を認め, 治療後の 芳香族アミノ酸值の改善 $(188 \pm 30$ vs $292 \pm 30 \mathrm{nM}, \mathrm{p}<$ $0.01)$, 生存時間の延長 $(24.8 \pm 1.9$ vs $15.8 \pm 0.8$ 時間, $\mathrm{p}<0.03)$ を認めた。

〔検討 2〕ラット急性肝不全モデル $(68 \%$ 肝切除, $24 \%$ 肝壊死， $8 \%$ 正常肝)を用い人工肝藏の残存肝への 効果を検討した。治療時間は肝不全導入後 4 時間目か ら 4 時間行い, 体外循環のみの群を対照とした。肝不 全導入後 12 時間目 (治療終了後 4 時間) の血中の增殖因 子および残存肝の転写因子活性について比較した。治 療群において血中 TGF- $\beta$ が有意に減少し (16 \pm 6 vs $26 \pm 7 \mathrm{ng} / \mathrm{m} l, \mathrm{p}<0.05)$, 残存肝における増殖と関連す る転写因子である Activator protein-1 (AP-1) と肝特 異的機能の発現を調節する Hepatocyte Nuclear Factor-1(HNF-1)の DNA 結合能の改善が認められた。

[考察]これらの結果から, われわれの人工肝蔵は, 有害物質の除去と傷害肝の再生と機能を改善すること が示唆された. しかし，タンパク合成能については, 良好とは言えず，また，本実験モデルにおいては，治 療後の生存時間の影著な延長には慗がらなかった。今 後, 細胞の培養形態や必要細胞数, 機能時間などの点 
でさらなる検討を要するものと考えられた。

\section{S4-2 コラーゲンゲル包埋ブタ肝細胞を用いたバイオ} 人工肝補助システム

仲 成幸 ${ }^{1}$, 竹下 和良 $^{1}$, 柿原 直樹 ${ }^{1}$ 山本 拓実 ${ }^{1}$, 鈴木 雅之 ${ }^{1}$, 石橋 治昭 ${ }^{2}$ 谷 徹 ${ }^{1}$, 小玉 正智1

（聯賀医科大学第 1 外科，2能登川病院外 科)

〔はじめに〕我々は，急性肝不全患者に対する治療を 目的として，生命維持に必要な肝機能の代行能力を有 するバイオ人工肝の開発研究を行ってきた．急性肝不 全時において求められる人工肝としての機能は, 肝臓 移植を受けるまでの橋渡しとして，アンモニア代謝な どの解毒機能による意識レベルの改善と血液凝固系機 能の改善による循環動態の安定が求められると考えら れる。これに対して我々は，細胞外マトリックスであ るコラーゲンゲルに包埋した肝細胞をホローファイバー 型モジュールの中空系外腔に充填することにより，肝 細胞を高機能を維持しながら高密度に培養することが 可能であることを示し，これを応用した人工肝補助シ ステムを開発した。

【実験方法〕ブタ肝実質細胞を I 型コラーゲンと混和 し，ホローファイバー型モジュールの中空系外腔に注 入し，コラーゲンをゲル化させたものを人工肝モジュー ルとして使用した(組み込み細胞数； $5.4 \times 10^{9}$ cells)。こ の肝細胞の plasminogen activator inhibitor I (PAI - I )の mRNA の発現をノーザンブロット法により検討 した。次に，約 $20 \mathrm{~kg}$ のブタを用いた急性虚血性肝不全 モデルに対し12時間の人工肝補助を施行し，血中アン モニア濃度，プロトロンビン時間，血中乳酸值等の肝 機能指標および生存時間につき検討した。

〔結果〕ノーザンブロット法による解析では，分離直 後の肝細胞では PAI- I の mRNA の発現を認めなかっ たが，培養48時間後の人工肝モジュール内の肝細胞で は PAI- I の mRNA の発現を単層培養の肝細胞に比べ 2 倍程度強く認めた。また，虚血性肝不全モデルに対 する人工肝補助システムによる治療実験では, 血中ア ンモニア濃度の上昇が治療群において有意に抑制され た. PT 值, ヘパプラスチン值では治療群と非治療群に 有意差を認めなかったが，手術創および肺出血を含め た出血傾向の出現時期は治療群において非治療群に比 べ遅延を認めた。生存時間は治療群は非治療群に比べ 2 倍の延長を認めた。
〔まとめ〕 in vitro 並びに，ブタ急性肝不全モデルを 用いた体外循環による治療実験により, 宿主肝蔵に対 して約 $7 \%$ の肝細胞を組み込んだバイオ人工肝モジュー ルによって，アンモニア処理など解毒機能についてほ ほ完全に代行が可能であり, 凝固系についてもプロト ロンビン時間などの血液データには反映されないが, バイオ人工肝モジュール内の肝細胞において顕著に誘 導発現される PAI- I により，出血傾向が抑制され循環 動態の安定化が可能であることが明らかとなった。

\section{S4-3 パイオ人工肝臟への応用を目的とする充填層型 リアクタの開発ーリアクタの性能改善とスケール アップー}

柳 健一 ${ }^{1}$, Thein Tun ${ }^{1}$, 三好 浩稔 ${ }^{1}$

谷口 秀樹 ${ }^{2}$, 高田 泰次 ${ }^{2}$, 深尾 立 $^{2}$ 大島 宣雄 ${ }^{1}$

(1筑波大学基礎医学系医工学, 2 同 臨床 医学系外科)

索引用語：バイオ人工肝蔵，充填層型リアクタ， polyvinyl formal 樹脂多孔質体

〔緒論〕重症肝不全の治療の切り札として, 肝細胞培 養系を利用するバイオ人工肝臓の開発が活発になされ, 欧米において臨床応用が開始されている，臨床応用が 可能なバイオ人工肝臓を開発するためには，肝細胞を 高密度かつ大量に培養すると共に，培養細胞の機能を in vivo と同等に維持する必要がある．培養血を用いる 小規模な培養系においては肝細胞は良好な機能を発現 することが知られている. しかし, 高密度・大量培㟍 系においては, 物質移動の効率が制限されることなど から，その機能を維持するのは容易ではない．著者ら は，多孔質の樹脂である polyvinyl formal(PVF)樹脂 多孔質体を細胞固定化用の担体として用いる充填層型 リアクタの有用性について報告してきた ${ }^{1 \sim 4)}$ 。特に，培 地中の溶存酸素濃度を通常よりも高く維持することに より,リアクタの性能を改善できる可能性を示した ${ }^{5)}$. 本稿ではこれらの結果について概説すると共に, リア クタのスケールアップの試みについて報告する.

〔方法〕1）リアクタの性能改善：肝細胞固定化用の 担体として，平均孔径が $250 \mu \mathrm{m}$ の PVF 樹脂を $2 \times 2 \times$ $2 \mathrm{~mm}$ に細切して用いた。この担体 250 個（担体体積 $\left.2 \mathrm{~cm}^{3}\right)$ を内径 $20 \mathrm{~mm}$ のリアクタに充填し，充填層型リ アクタとした．肝細胞は Wistar 系雄性ラットからコラ ゲナーゼ灌流法により遊離した。 8.2 19.7 $\times 10^{7}$ 個 $(\mathrm{n}=$ 6)の細胞浮遊液をリアクタの上部から注入して肝細胞 
を播種した。同時にリアクタの下部からシリンジを用 いて培地を吸引し，担体内に捕捉されなかった細胞を 除いた.リアクタとリザーバの間で $100 \mathrm{~m} l$ の培地を50 $\mathrm{m} l / \mathrm{min}$ の速度で灌流し, 2 日間の灌流培養を行った。 リアクタの上流に酸素加装置を置き, 培地を酸素化し た. リアクタの下流に置いた酸素電極と $\mathrm{pH}$ 電極により 溶存酸素濃度と $\mathrm{pH}$ を測定し，それぞれ $40 \%$ と 7.4 とな るように酸素加装置への通気中の酸素濃度と炭酸ガス 濃度を調整した。肝細胞のアンモニア代謝能，アルブ ミン分泌能を評価した。培養実駼終了後, リアクタ内 に固定化された肝細胞数を測定した. 走查型電子顕微 鏡, 透過型電子顕微鏡にて形態学的観察を行った. 対 照として, コラーゲンコートディッシュを用いる単層 培養を行った。

2) リアクタのスケールアップ: 灌流培養システムに ついては, 上記の小規模なリアクタシステムと同じ構 成のものを用いた。担体のサイズは $3 \times 3 \times 3 \mathrm{~mm}$ とし， 担体 2,500 個 (担体体積 $67.5 \mathrm{~cm}^{3}$ ) を内径 $50 \mathrm{~mm}$ のリア クタに充填した. ブタから採取した肝細胞(1.5〜 4.8× $10^{9}$ 個, $\left.\mathrm{n}=5\right)$ を播種して $500 \mathrm{~m} l$ の培地を $200 \mathrm{ml} / \mathrm{min}$ の速度で灌流した。

〔結果〕1）リアクタの性能改善：用いた肝細胞の播 種方法により, 約 $80 \%$ の肝細胞がリアクタ内に保持さ れた。 2 日間の灌流培養終了後には, 培養開始時に保 持された生細胞の $40 \sim 60 \%$ が PVF 樹脂内に固定化さ れ, リアクタ内の肝細胞密度は $1.9 \pm 0.4 \times 10^{7} \mathrm{cells} / \mathrm{cm}^{3}$ -PVF となった。一方, 肝細胞のアンモニア代謝能及び アルブミン分泌能は, 対照として行ったコラーゲンコー トディッシュを用いる単層培養と同等の良好な值を示 した，走査型電子顕微鏡による観察では，肝細胞は球 状の形態を保ち, 一部には凝集塊の形成が観察された。 また, 細胞は担体の表層部分だけでなく, 中心部まで 分布していた. 透過型電子顕微鏡による観察では, 肝 細胞は生体内と同様の形態を示した。すなわち, 円形 の核, 豊富なミトコンドリア, 粗面小胞体, ゴルジ装 置, グリコーゲン顆粒などの細胞内小器官を認めた。 また，隣り合う細胞間には，接着班を形成すると共に 毛細胆管の形成が観察された。

2) リアクタのスケールアップ: スケールアップした リアクタにおいても, 細胞播種時にリアクタ内に保持 された肝細胞の50〜80\%が24時間の培養後に PVF 樹脂

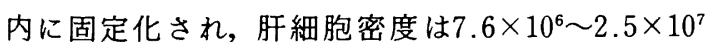
cells $/ \mathrm{cm}^{3}-\mathrm{PVF}$ となった。この結果, 最大で $1.7 \times 10^{9}$ 個の肝細胞がリアクタ内に固定化された。培養第 1 日
の時点における肝細胞当りのアンモニア代謝能は対照 として行った単層培養の代謝能の約 $80 \%$ の值を示した. 次に, このリアクタを用いて 4 日間の連続培養を行っ た.リアクタ内の固定化肝細胞数は培養経過と共に減 少し, 培養終了時には培養第 1 日の約 $60 \%$ となった. 一方, 肝細胞当りのアンモニア代謝能は培養経過中に 低下することなく同じ値を保った。

〔結語〕 PVF 樹脂多孔質体を担体とする充填層型り アクタにより, 肝細胞を $2 \times 10^{7} \mathrm{cells} / \mathrm{cm}^{3}-\mathrm{PVF}$ の高密 度で, 代謝能をディッシュを用いる単層培養と同等に 維持して培養可能である. 本リアク夕は代謝能を良好 に維持したままスケールアップ可能であり,バイオ人 工肝臓の開発に有用である.

謝辞 本研究は日本学術振興会, 未来開拓学術推進事 業(JSPS-RFTF96I00202)の一部として行われている. 文 献：1）Ohshima $\mathrm{N}$ : Tissue engineering aspects of the development of bioartificial livers. J Chin Inst Chem Engrs 28:441-453, 1997 2) Ohshima N, Yanagi K and Miyoshi H : Packed-bed type reactor to attain high density culture of hepatocytes for use as a bioartificial liver. Artif Organs 21 : 1169-1176, 1997 3) Yanagi K, Miyoshi $\mathrm{H}$, Fukuda $\mathrm{H}$ and Ohshima $\mathrm{N}$ : A packed-bed reactor utilizing porous resin enables high density culture of hepatocytes. Appl Microbiol Biotechnol $37: 316-320,1992$ 4) Miyoshi H, Yanagi K, Fukuda $\mathrm{H}$ and Ohshima $\mathrm{N}$ : Long-term continuous culture of hepatocytes in a packed-bed reactor utilizing porous resin. Biotechnol Bioeng 43 : 635-644, 1994 5) Yanagi K, Miyoshi $\mathrm{H}$ and Ohshima $\mathrm{N}$ : Improvement of metabolic performance of hepatocytes cultured in vitro in a packedbed reactor for use as a bioartificial liver. ASAIO J $44:$ M436-440, 1998

\section{S4-4 不織布充媜型人工肝臓バイオリアクターを用い} た異種灌流実験の検討

成瀬 勝俊 ${ }^{1}$, 酒井 康行 ${ }^{2}$, 郭 雷 ${ }^{1}$

針原康 ${ }^{1}$, 鈴木 基之 ${ }^{2}$, 幕内 雅敏 ${ }^{1}$

( ${ }^{1}$ 東京大学人工臟器移植外科, ${ }^{2}$ 同 生産 技術研究所)

索引用語: 不織布充填型人工肝臓バイオリアクター, イヌ肝不全モデル，異種灌流実験

本年, 我が国初の脳死肝移植が行われたが，なお世 界的に深刻なドナー不足の状況にあって待機中に死亡 する移植適応患者も多い.これらの患者のドナーが得 
られるまでのつなぎの治療法, そして, 劇症肝炎, 術 後肝不全の治療法として, ハイブリッド型人工肝臓に 大きな期待が寄せられている，我々は，肝細胞と灌流 血液が直接接触することで良好な物質交換能を発揮し, かつ肝細胞を大量に充填することのできる不織布充填 型人工肝㵴バイオリアクターを開発し，これが in vitro 実験及びブタ肝細胞を用いた ex vivo 同種灌流実験に おいて良好な性能を発揮することを示してきた ${ }^{1 \sim 3)}$. 今 回，このバイオリアクターにブタ肝細胞を充填し，イ 又肝不全モデルに対する異種灌流実験を行った。

ブタ全肝より肝細胞を分離し，ポリエステル不織布 を充填したカラムに 1 本あたり $1.0 \times 10^{10}$ 個を 24 時間灌 流して固定化し，不織布充填型バイオリアクターを作 成した。翌日, 門脈下大静脈シャント, 肝門部におけ る脈管結禁によりイヌ肝不全モデルを作成し，頭蓋内 圧をモニターした上で, 血漿分離器, リザーバー, 及 びリザーバーに別系に接続した免疫グロブリン吸着除 去装置とバイオリアクター 2 本からなるハイブリッド 型人工肝臓システム(Fig. 1) による異種灌流治療を行っ た. 灌流治療は，モデル作成後 7 時間目に全血灌流か ら開始し，その $5 〜 10$ 分後に血獎分離を開始した． 30 分かけてリザーバーに約 $200 \mathrm{~m} l$ の肝不全血獎をため, その時点で別系に接続したバイオリアクターの灌流を 開始し，これを 2 時間かけて行った。総灌流時間は 7 〜10時間にかけての 3 時間であった。肝不全群( $\mathrm{LF}$ 群), 肝細胞を充填しないカラム群 ( $\mathrm{Col}$ 群), 肝細胞を充填し たバイオリアクター群(Bio 群), 免疫グロブリン吸着除 去装置を併用する臨床用システム群 $(B i o+I M$ 群) の 4 群に分け(各群とも $\mathrm{n}=4$ ), 血液及び脳脊䑷液デー夕を
比較した.

代謝解毒能の評価としては，LF 群においては，血液 中及び脳脊髄液中のアンモニア, 血液中の胆汁酸の持 続的上昇, 血液中及び脳脊髄液中の Fischer 比の持続 的減少, 血液中のオルニチンの持続的減少, 脳脊髄液 中のグルタミンの持続的上昇を認めた。 $\mathrm{Col}$ 群及び Bio 群では, 血液中及び脳脊髄液中のアンモニアは灌流治 療中も持続的に上昇し, 血液中の Fischer 比は上昇を 認めたものの, 有意ではなかった，それに対し，Bio+ IM 群においては, 灌流治療前後で血液中の胆汁酸の減 少, 分枝鎖アミノ酸及び Fischer 比の上昇, オルニチン の上昇を有意に認めた。また, 脳脊髄液中の Fischer 比 の上昇, グルタミンの減少及び頭蓋内圧の減少を認め た。アンモニアは, 血液及び脳脊髄液とも, 灌流治療 中横這いで経過し，上昇の抑制が認められた(Fig. 2 ).

免疫学的評価としては, $\mathrm{IgM}$ 及び $\mathrm{C} 3$ は $\mathrm{Col}$ 群及び Bio 群でもリザーバー内で検出值以下であり, 血漿分離 器によってカットオフされることがわかった。一方, IgG 及び C5は, Col 群及び Bio 群では全血中の $1 /$ 3〜1/2の值で認められたが, Bio+IM 群においてはい ずれも検出值以下であった. Bio 群では，4 例中 3 例に おいて灌流実験の施行中に免疫複合体と考元られる白 色の浮遊物がバイオリアクターの回路に出現し, これ が回路に詰まって灌流続行が不可能となる例もあった。 一方, Bio+IM 群では, 実験中にこうした浮遊物は出 現せず，灌流は全く支障なく続行できた，免疫グロブ リン吸着除去装置によってグロブリンや補体が吸着さ れた結果, 異種免疫による拒絶反応が回避されたと考 えられた。

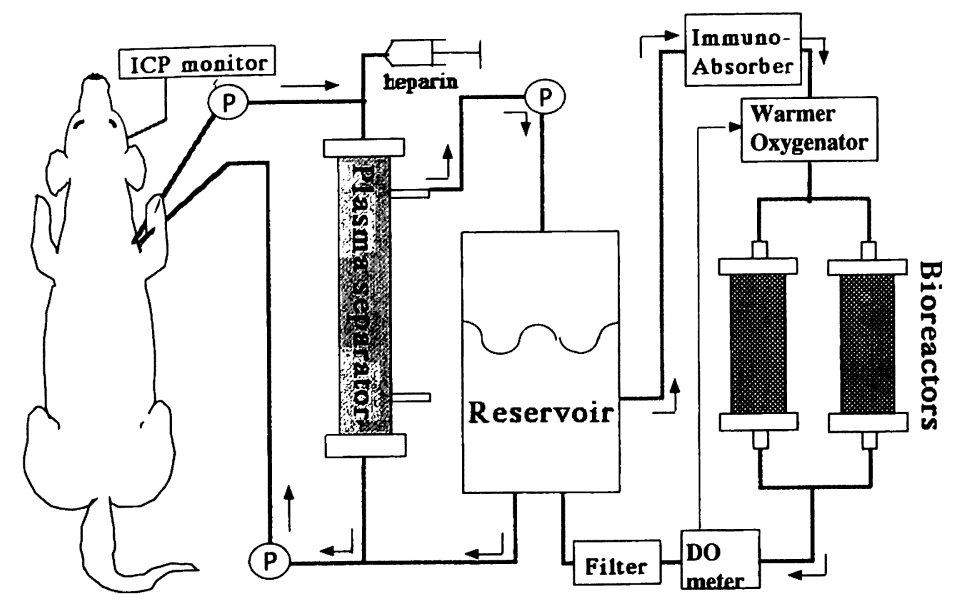

Fig. 1 Xenoperfusion Experiment 


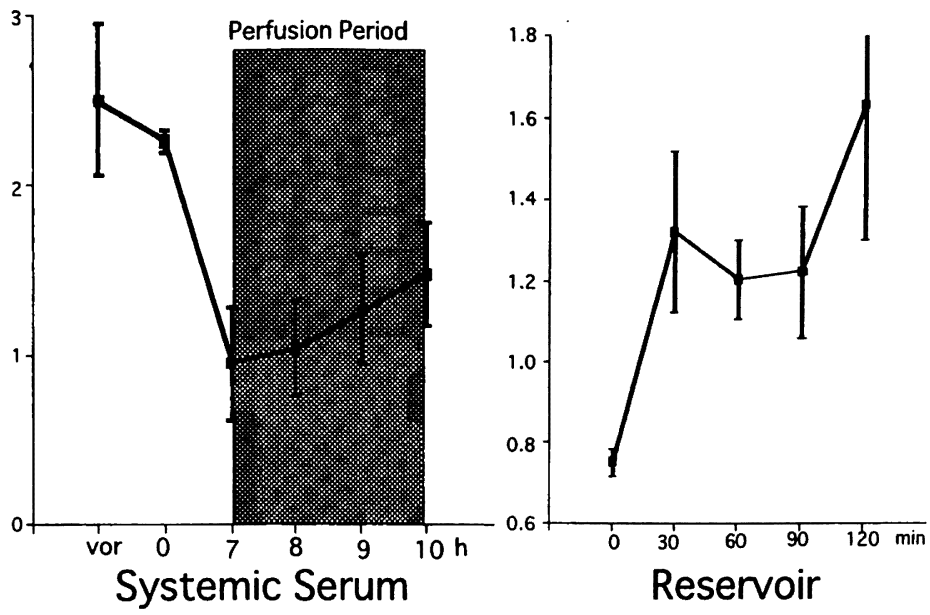

Fig. 2 Fischer's ratio of Bio-IM group

本実験により，不織布充填型バイオリアクターは, 免疫グロブリン吸着除去装置を併用したシステムを用 いることにより，異種肝細胞による灌流治療を円滑に 行うことができること，そして，肝不全患者の代謝解 毒能を代替し, 頭蓋内圧を下げて肝性昏睡を治療する 可能性を持つことが示された。

文 献：1）Naruse K, et al：Development of a new bioartificial liver module filled with porcine hepatocytes immobilized on non-woven fabric. Int J Artif Organs 19(6)：347-352，1996 2) 成瀬勝俊, 他：不織布充填型人工肝藏バイオリアクターを用いた フタ同種灌流実験の検討. 肝臓病学の最前線 1997 319-23, 中外医学社 3) Naruse K, et al： Efficacy of a bioreactor filled with porcine hepatocytes immobilized on nonwoven fabric for ex vivo direct hemoperfusion treatment of liver failure in pigs. Artif Organs 22(12) : 1031-7, 1999

\section{S4-5 臨床応用可能な人工肝嵗の開発}

山下 洋市 ${ }^{1}$, 島田 光生 ${ }^{1}$, 調 憲 ${ }^{1}$ 祇園 智信 ${ }^{1}$, 濱津 隆之 ${ }^{1}$, 力丸 竜也 ${ }^{1}$ 井嶋 博之 ${ }^{2}$, 中澤 浩二 ${ }^{2}$, 金子 充 $^{2}$ 福田 淳二 ${ }^{2}$, 船津 和守 ${ }^{2}$, 杉町 圭蔵 ( ${ }^{1}$ 九州大学第 2 外科, ${ }^{2}$ 同 大学院工学研 究科)

索引用語 : 多細管型ポリウレタンフォーム/肝細胞ス フェロイド培養系人工肝臓, 臨床用大型 モジュール
〔背景・目的〕我々は, 多細管ポリウレタンフォーム (PUF)/肝細胞スフェロイド培養系人工肝臓を開発し,

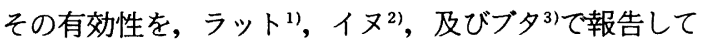
きた。 今回我々は, 本人工肝臓の臨床応用に向けて, 臨床用大型モジュールの作製に成功し, 良好な機能発 現を確認したので報告する。

〔方法〕（検討 1 ）臨床用大型モジュールの性能評価： $25 \mathrm{~kg}$ 家畜ブタを用い, 門脈・下大静脈吻合後に肝動脈 を結惄する温虚血肝不全モデルを作製した。臨床用大 型モジュール (PUF 充填体積 $766 \mathrm{~m} l$, 固定化ブ夕肝細胞 量 $1 \times 10^{10}$ 個 $($ 約 $\left.100 \mathrm{~g})\right)$ を 2 本並列に適用した人工肝群 $(\mathrm{n}=2)$ と, 肝細胞を含まないモジュールのみを適用し た対照群 $(n=1) に$, 生存時間及び血中アンモニア濃 度などの肝機能指標を比較した。

(検討 2 ) ヒト血漿中での機能評価とブタ肝細胞障害 の制御 : 小型モジュール(PUF 充填体積 $15 \mathrm{~m} l$, 固定化 肝細胞量 $2 \times 10^{8}$ 個 $)$ をヒト肝不全血獎 $(150 \mathrm{~m} l)$ で 3 日間 灌流培養し，アンモニア代謝を検討した。また，ヒト 正常血清を無処置, 非働化, Nafamostat mesilate (NM) $0.05 \mathrm{mg} / \mathrm{m} l$ にて処理し, 各血清でブタ肝細胞を 培養してその生存率を比較した。

〔結果〕（検討 1 ）生存時間は, 対照群が約 13 時間, 人工肝群の平均が約 26 時間と約 2 倍の延長効果を認め た。血中アンモニア濃度に関しては, 対照群が 6 時間 $て ゙ 600 \mu \mathrm{g} / \mathrm{d} l, 12$ 時間で $1100 \mu \mathrm{g} / \mathrm{d} l$ を越えて上昇したの に対し，人工肝群では，1例では20時間を越えて 150 $\mu \mathrm{g} / \mathrm{d} l$ 前後を維持でき，もう 1 例では 6 時間まで 150 $\mu \mathrm{g} / \mathrm{d} l$ 前後を維持し, その後軽度上昇を認めるのみだっ 
$80: 230$

た.また，人工肝群で血糖値の維持効果が見られた。

（検討 2 ）小型モジュールをヒト肝肝不全血漿で灌流 培養した結果，アンモニアは 2-3 日間正常域まで良好 に代謝した。また，ヒト血清を非動化，Nafamostat mesilate(NM)にて処理した群において, 非処理群に比 しブタ肝細胞障害が軽度であった。

〔結論〕臨床用大型モジュールのブ夕温虚血肝不全モ デルにおける良好な機能発現を確認した。 また，ヒト 血槳中での機能発現及び薬剤による異種免疫反応の軽 減を確認した。 以上より, 我々の人工肝蔵は, 充分に 臨床応用可能であると考える。

文 献：1) Ijima H, Matsushita T, Nakazawa K, Fujii Y, Funatsu K: Hepatocyte Spheroid in Polyurethane Foams: Functional Analysis and Application for a Hybrid Artificial Liver. Tissue Engineering 4(2):213-226, 1998 2) Ijima $\mathrm{H}$, Matsushita T, Nakazawa K, Koyama S, Gion T, Shirabe K, Shimada M, Takenaka K, Sugimachi K, Funatsu K : Spheroid Formation of Primary Dog Hepatocytes Using Polyurethane Form And Its Application to Hybrid Artificial Liver. Animal Cell Technology 577-583, 1997 3) Kaneko M, Fukuda J, Ijima H, Matsushita T, Nakazawa K, Gion T, Shimada M, Shirabe K, Takenaka K, Sugimachi K, Funatsu K : Development of hybrid artificial liver support system using spheroid culture and application to warm ischemic liver failure in dog and pig as a preclinical test. Material Science and Engineering C6 1998, 245-248

S4-6 リアクターの形状よりみた人工肝開発の現況と 問題点一長期肝機能補助を目指した回転式ラジア ルフロー型パイオリアクターの開発一 宮澤 光男 ${ }^{1}$, 島津 元秀 $^{2}$, 上田 政和 ${ }^{2}$ 北島 政樹 ${ }^{2}$

( ${ }^{1}$ 国立病院東京医療センター外科, ${ }^{2}$ 慶應 義塾大学外科)

欧米におけるバイオ人工肝の臨床応用は「移植まで のブリッジ」として有用性が報告されている゙1). しかし， 本邦では，脳死肝移植が開始されたとはいえ，ドナー 肝の獲得は困難であり，人工肝の果たすべき役割は自 ずと欧米とは異なってくる，つまり，欧米よりは長期 間の肝機能補助が必要であり,さらには, 肝細胞壊死 を阻止し, 肝不全肝を良好な肝再生に導くような人工 肝の開発が求められる.バイオ人工肝において高度の
41 巻 3 号 $(2000)$

肝機能を長期維持するためには多くの検討すべき点が あるが，リアクターモジュール内の検討事項は, 細胞 自体, 細胞を付着させるマトリックス,さらには, 細 胞を封入するリアクターの形状である，本稿では，特 にリアクターの形状に焦点を絞ったバイオ人工肝の現 況と問題点に関してと, それらの問題点を踏まえ, 我々 が開発している回転式ラジアルフロー型バイオリアク ターを利用したバイオ人工肝について述べる.

〔リアクターの形状よりみた現況と問題点〕リアクター の形状としては, ホロファイバー型とラジアルフロー 型が主流と考えられる. 各々の特徴を整理すると以下 のようになる. ホロファイバー $(\mathrm{HF})$ 型リアクターの問 題点：1）栄養源や酸素供給, 代謝産物の濃度勾配 (ファイバーより離れた肝細胞の物質交換が不良).2) 血槳の流速による剪断応力の影響(ファイバー外腔に生 じる対流の問題).3）重力による細胞の沈降４）不完 全な三次元培養(マイクロキャリア等に付着させる場合 は完全な三次元培養とはならない)，5）スケールアッ プの問題(ファイバーを長くするとファイバーの屈曲, 破損の問題が生じる)，等がある.ラアジアルフロー (RF) 型バイオリアクターの問題点：1）死滅した細胞が 障害となり, 圧格差ができ, 圧の低い所のみを培養液 が流れ，均一な培湌ができない，2）肝細胞を接着させ る担体，マトリックス選択が困難である．3）担体，マ トリックスを密に，均一に充填することが困難である. 4）肝細胞を均一に播種することが困難である．5）リ アクター内において免疫隔離を行うことができない, 等がある. また, $\mathrm{HF}$ 型, $\mathrm{RF}$ 型の最大の利点は, $\mathrm{HF}$ 型：免疫隔離がある程度行える。 RF 型：比較的良好な 物質交換が行える, ことである. 上記の問題点, 利点 を考慮すると, ドナー肝を獲得することが非常に困難 である本邦においては，より効果的な肝機能補助がで きる可能性を有する点において RF 型リアクターの方が 適当と考えられる2). 欧米においては，異種細胞に対す る免疫隔離を目的として, 主に HF 型リアクターの開 発が行われている. しかし，封入されている肝細胞数， あるいは, 物質交換の効率からみて, 長期の肝機能補 助として十分とは考えられず，本邦においては適応と はならないであろう。いずれにしても，劇症肝不全に おいて，何を除去し，何を免疫隔離し，何を人工肝に よって産生しなければいけないかを明確にし，それに 見合ったバイオ人工肝を作成することが肝要であろう と考える゙!.

〔回転式ラジアルフロー型バイオリアクター〕従来の 


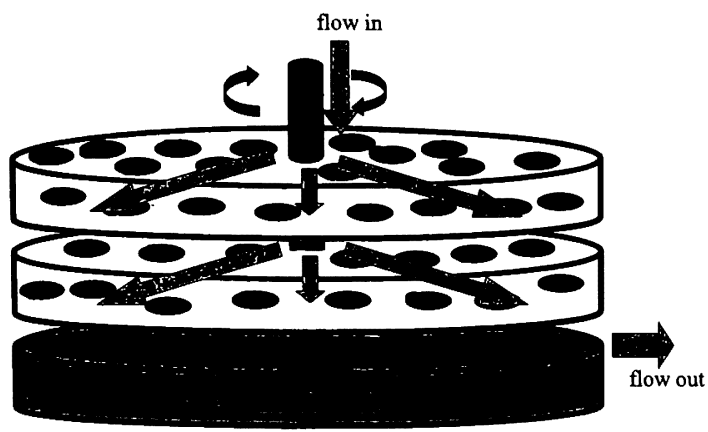

Fig. 1 Model of the rotating radial-flow bior eactor (RRFB) with radial center -to-edge flow. The hepatocytes are attached on the gauze coated by type 1 collagen. The bior eactor itself is rotated on the stirrer.

$\mathrm{RF}$ 型の問題点を解決し, 流体力学的にはリアクターと して最良と考えられる回転式ラジアルフロー型バイオ リアクター(RRFB)を開発した。この RRFB はスター ラー上で肝細胞の付着したマトリックスが回転するこ とにより，RF 型リアクターにおける，死滅した細胞に より圧格差が生じ，均一な流れが得られないという問 題点の解決を目指している，培養実験において，この リアクターは肝細胞に一定の遠心力を加えることがで き，肝細胞の aggregate を導く作用があった.このこ とは,このリアクターを利用することにより，肝細胞 機能を長期に維持できる可能性がある。アンモニア代 謝実験において，RRFBは，静地培養，シランを担体 とした灌流培養と比較して，培養早期のアンモニア代 謝能に優れているという結果が得られた. バイオ人工 肝システムセットアップ早期における肝機能発現にお いても，有利である可能性があると考えている．本邦 において人工肝の役割は, 移植までの「ブリッジ」と してばかりではなく, Native 肝の肝再生を促進するよ うな効果も求められている。この要求を満たすべく, 今後検討すべき事項としては，1）肝細胞機能発現に優 れた Matrix の開発4)．2）肝非実質細胞との混合培養 による, 長期高度肝機能維持. 3) 培養液が持続的に流 れるような Matrix の開発. 4) 免疫隔離の問題. 5) ス ケールアップの問題, 等の点と思われる.これらの点 が解決されれば, 将来的に, 体外において肝臓を作成 することが可能であろうと考えている.

文 献：1) Watanabe FD, Rozga J, Demetriou $A$, et al : Clinical experience with a bioartificial liver in the treatment of severe liver failure. A phase I clinical trial. Ann Surg 225:484-491, 1997 2) Ledezma GA, Folch A, Yarmush ML, et al: Numerical model of fluid flow and oxygen transport in a radial-flow microchannel containing hepatocytes. J Biomech Eng 121:58-64, 1999 3) Arkadopoulos N, Rozga J, Demetriou AA, et al : Liver assist systems : state of the art. Int $\mathrm{J}$ Artif Organs 21:781-787, 1998 4) Miyazawa M, Ueda M, Kitajima M, et al : Development of a novel matrix for mesenteric hepatocyte transplantation. Gastroenterology 114：L0428, 1998

\section{S4-7 ヒト肝細胞を用いた人工肝補助装置の解毒代謝} 能評価

川田 雅昭 ${ }^{1}$, 清水 英佑 ${ }^{1}$, 松浦 知和 ${ }^{2}$ 蓮村 哲 ${ }^{2}$, 永森 静志 ${ }^{2}$, 小林カオル ${ }^{3}$ 細川 正清 ${ }^{3}$, 千葉 寛 ${ }^{3}$

( ${ }^{1}$ 東京慈恵会医科大学環境保健医学, ${ }^{2}$ 同 内科学第 1,3 千葉大学薬学部薬物学)

〔目的〕ヒト生体にとって最も理想的な代用肝は, 蛋 白産生や糖, 脂質代謝, 解毒能を備えたバイオ人工肝 ${ }^{11}$ である. 使用される細胞は, 正常機能を備え, かつ増 殖能力にすぐれたヒト肝細胞が, 最適であるが, 総て の機能がヒト正常肝細胞に匹敵する細胞は知られてい ない. ヒト正常肝細胞の利用は倫理的問題が解決され ていない上, in vitro での増殖力は極めて弱く, 機能維 持は困難である。ヒト肝癌由来細胞 ${ }^{2,3)}$ や遺伝子操作に より増殖能を獲得したヒト肝細胞の中から, 部分的に せよ正常肝細胞の機能を維持した細胞株を組み合わせ て用いるのが，現状の目標といえる．正常肝に近似し た機能を備えた細胞と, その能力を充分引き出せる培 養システムの組み合わせが, バイオ人工肝発達のキー ポイントである. 肝不全治療を目的としたバイオ人工 肝の開発において, 培養装置(ラジアルフロー型バイオ リアクター, RAD) ${ }^{4}$ の機能評価のひとつとして解毒代 謝能を検討する. ヒト肝癌細胞株 FLC4,5,7各細胞 ${ }^{5)}$ 培養し, 解毒代謝の主要酵素であるチトクローム P450(CYPs) とカルボキシルエステラーゼ(CES-Hu1, Hu3)の蛋白発現, 代謝活性, その誘導について検討し た.

〔方法〕用いた RAD は, 担体充填層が円筒形で, 外 側面から中心軸へ向かい培地を循環させるため, 従来 のリアクターに比べ, 酸素や栄養源を, 培地の剪断力 を極力緩和して, 比較的均等に供給可能となってい 
る.このため, 理論上70リットル容量までスケールアッ プ可能であり，以下の特徵を備える．細胞を接着させ る担体は，細胞培養にはあまり条件の良くないガラス 担体を用いているが，単層培養に比べ，より効率的に 細胞機能を発揮することが $\mathrm{CHO}, \mathrm{BHK}$ 細胞でも確認 されている4).八イドロキシアパタイトなど組織親和性 のより強い担体への転換も準備段階に入っている，担 体選択の条件は硬質骨格構造を備えていないと, 細胞 接着とともに, 重力で沈降する問題が生じる，逆に言 えば，柔らかい担体では，高密度大量培養は困難と考 えられる。細胞播種時には, 細胞㲘濁液が培地ととも に, 均等な細胞濃度と速度で, 担体充填層に流入する ため重力の影響を極力受けずに，比較的均一に播種で きる. 実際の臨床応用には免疫隔離の問題が生じるが, これは他のバイオリアクターにも共通の問題であり, 今後の課題である. FLC 細胞は, RAD 内で高密度三 次元培養された後, 担体から回収され, マイクロゾー 么分画が抽出された. Western blotにて各分子種蛋白 量を測定した. CYP1A や3A を介した代謝活性測定は, HPLCを用いた。

〔成績〕FLC series は, ethoxyresorfin と testosterone を基質としたCYP1A，3A 活性を認め，これらは， 各々 omeprazole と rifampicinにより, 濃度依存性に 活性上昇することから，CYP1A，3A 活性の誘導がか かることが確認された，RAD培養された FLC series の CYP 分子種の Western blot による蛋白測定では, CYP1A1，1B1，2E1，3A4の蛋白発現を認め, (CYP1 A1 : 1-2 pmol/mg-microsome protein)FLC5細胞で は, $\mathrm{CYP} 2 \mathrm{C}$ 蛋白も確認された。これらは単層培養と比 較して明らかに高発現しているものはなかった。 また, 抗凝固剤 nafamostat mesilate は RAD 培養された FLC4細胞により代謝され，代謝産物の上昇を認めたこ とから, CES 活性が確認され, FLC series で CES 分 子種 $\mathrm{Hu} 1, \mathrm{Hu} 3$ の各蛋白発現も認めた。特に RAD 培 養された FLC5細胞では, CES-Hu1において単層培養 の30倍の蛋白発現を認めた。

〔結論〕バイオ人工肝には，主に細胞とその培養シス テムの 2 つの要素がある. 培養装置は, RAD の培地の 流れが理論上理想的である. 担体の組織親和性や孔径 に改善の余地がある. 使用細胞は, その代謝機能, 醉 素活性の検討を要し, CYP, CES には種差があり, 分 子種活性が異なることを考慮する必要がある。また誘 導の効果, 活性の上昇度を把握して, 代謝実験を行う 必要がある。これらの細胞機能を把握したシステムの
確立が，今後の課題と考えられる.

文 献：1）永森静志, 蓮村 哲, 松浦知和, 他: 消 化器疾患における in vivo と in vitro の接点一肝細胞 研究から臨床応用への道一.「21世紀を目指して羽ば たく消化器病学」原田 尚編, 日本医学館, 東京, 1993，p414-418 $\quad$ 2) 永森静志, 藤瀬清隆, 蓮村 哲, 他：ヒ卜培養肝細胞の産生物質. Human Cell 1:382-390, 1988 3) Nagamori S, Hasumura S, Shimizu K, et al: Relation Between AlbuminPositive Hepatocytes and Glutathione-S. Transferase-Positive Foci in Nagase Analbuminemic Rats Treated with 3'-Methyl-4 Diaminoazobenzene. J Toxicologic Pathology 5: $39-46,1992$ 4) 水谷 悟: ラジアルフロー型バイオ リアクター。組織培養工学 $18: 249-254,1992$ 5) 蓮村 哲, 筋野 甫, 永森静志, 他: 七上肝細胞癌由 来細胞株 JHH-4株の樹立とその性状. Human Cell $1: 98-100,1988$

\section{S4-8 転写制御因子 hepatocyte nuclear factor 活性} 化を応用したパイオ人工肝の開発

永木 正仁 ${ }^{1}$, 内木 隆文 ${ }^{1}$, 杉山 昭彦 ${ }^{1}$ 大西 弘生 ${ }^{1}$, 武藤 泰敏 ${ }^{1}$, 森脇 久隆 ${ }^{1}$ 金 良一 ${ }^{2}$, 三木敬三郎 ${ }^{3}$, 石山 晴生 ${ }^{3}$ 四童子好広 ${ }^{4}$, 小島 久典 ${ }^{4}$

( ${ }^{1}$ 岐阜大学第 1 内科, ${ }^{2}$ 慶北大学外科, ${ }^{3}$ 广 ルモ研究開発センター, ${ }^{4}$ 応用生化学研究 所)

索引用語：バイオ人工肝, 転写因子, 急性肝不全 〔はじめに〕バイオ人工肝の開発には, 肝細胞に長期 間, 高度の肝細胞特異的機能を発現させうるコンパク 卜な体外灌流システムの確立が最も重要である。我々 は細胞外マトリックスによる肝細胞分化機能発現作用 に注目し，種々の細胞外マトリックスを検討した結果， 基底膜類似成分で構成される EHS(Engelbreth-HolmSwarm) ゲルが, 最も長期間, 肝細胞特異的遺伝子の 発現を維持し，さらにその作用は転写制御因子である hepatocyte nuclear factor (HNF) -1 ならびに-4を介 して制御されていることを報告してきだ1).今回，EHS ゲルを応用したバイオ人工肝モジュールの臨床応用を 目標に, 大型哺乳動物を用いて本バイオ人工肝の有効 性を検討するとともに，バイオ人工肝への応用を目的 に, HNF-4を肝細胞に遺伝子導入することで, より高 度の肝細胞特異的機能を発現するスーパー肝細胞の確 立を目指している. 
〔方法〕約 $10 \mathrm{~kg}$ のブタより，肝細胞を分離した後， $10^{8}$ cells $/ \mathrm{m} l$ の濃度になるよう EHS gel に眯濁し，木 ロファイバーの extracapillary space に充填した。虚 血性肝不全ブタは, 約 $40 \mathrm{~kg}$ のブタを用い, 門脈下大静 脈吻合後, 肝動脈を結禁離断し, 肝への血流をすべて 遮断することで作製した。血流遮断 8 時間後，バイオ 人工肝モジュール $(n=4)$ およびブタ肝細胞を含まない ホロファイバー $(\mathrm{n}=4)$ を連結し，体外灌流を行い，そ の治療効果として生存期間, 血液生化学デー夕を測定 した.

アデノウイルスの E1a，E1b，E3を欠失させて作製し た非増殖性アデノウイルスの E1部分に CAG プロモー ターを有したラットHNF-4遺伝子を組み込んだベクタ 一を作製し(図 1)，ラット初代培養肝細胞とヒト肝癌 株細胞である HepG2細胞や HuH7 細胞に感染させ，細 胞内の HNF-4をウエスタンブロット法で，培養液中の アルブミン濃度を ELISA 法にて測定した。

〔結果〕モデル作製後の生存時間はバイオ人工肝群 $(n=4): 26.0 \pm 8.8$ 時間, コントロール群 $(n=4)$ : $18.6 \pm 10.5$ 時間であり, 生存時間には有意差を認めな かった. しかし，バイオ人工肝群ではバイオリアクター 装着後より低下していた重炭酸イオン濃度は上昇し， 循環動態の安定が得られた。一方，コントロール群で は重炭酸イオン濃度の上昇はみられず，血圧は低值の まま推移した。また，バイオ人工肝群において，人工 肝モジュールを装着後より，上昇していた血液アンモ ニア值の低下が認められたが，コントロール群ではア ンモニア濃度の低下は認められなかった。

HNF-4を遺伝子導入されたラット初代培養細胞にお いて HNF-4の発現の増加と培養液中アルブミン濃度の 上昇が認められた。また, HepG2細胞や $\mathrm{HuH} 7$ 細胞で も培養液中へのアルブミン分泌の増加が認められた。
〔結論・考察〕細胞の分化形質は特異遺伝子の発現 によってもたらされている.分化した細胞で特定の遺 伝子が発現するための機構として, 細胞特異的な転写 因子複合体の構築がある。例えばアルブミン遺伝子の 発現は，エンハンサー領域において種々の転写制御因 子によって制御されていることが判明している2． 既に 我々は，細胞外マトリックスによる肝細胞の分化機能 の発現, 維持が転写制御因子である hepatocyte nuclear factor (HNF) - 1 ならびに-4 を介して制御され ていることおよび種々の細胞外マトリックスの中で EHS ゲルが, 最も長期間, 肝細胞特異的遺伝子の発現を維 持することを報告してきた ${ }^{1}$. 転写制御因子 HNF を制 御するEHS ゲルを応用したホロファイバー型モジュー ルは, 急性虚血性肝不全ブタに対して血液中のアンモ ニアや乳酸を有効に代謝して抢り，体外灌流型ハイブ リッド人工肝の実現に向けて大きな可能性を持つ魅力 あるシステムであると考えられた。

細胞特異遺伝子の発現調節は転写レベルにおいて比 較的少数の中心的な制御因子によって調節を受けてい るため，そのヒエラルキーの上位に位置する遺伝子を 誘導することにより，より多くの遺伝子を一度に誘導 することが可能であると考えられる。そこで我々は， 転写制御因子である HNF-4を肝細胞に遺伝子導入する ことで分化形質を高度に発現したスーパー肝細胞を確 立し，それをバイオ人工肝に応用しょうと試みている。 ラット HNF-4遺伝子を組み込んだアデノウイルスベク ターは, ラット初代培養肝細胞や七ト肝癌株細胞にお いて, HNF-4遺伝子の発現, アルブミン分泌の増加を 誘導することにより，スーパー肝細胞の確立ならびに バイオ人工肝への応用に有望であると考えられた。

文 献：1) Nagaki M, Shidoji Y, Yamada Y, et

\section{Adenovirus DNA}

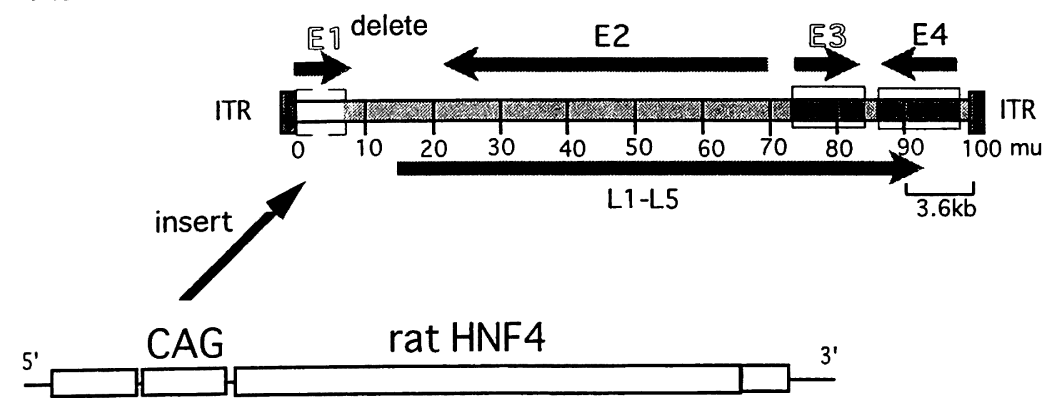

図 1 Recombinant adenovirus 
al : Regulation of hepatic genes and liver transcription factors in rat hepatocytes by extracellular matrix. Biochem Biophys Res Commun 210: $38-43,1995$ 2) Xanthopoulos KG, Prezioso VR, Chen WS, et al: The different tissue transcription patterns of genes for HNF-1, C/EBP, HNF-4, protein factors that govern liver-specific transcription. Proc Natl Acad Sci USA $88: 3807-3811$, 1991

\section{S4-9 肝細胞/星細胞の混合培養系と炎の臨床応用への} 展望

立野 知世 ${ }^{1}$, 山崎ちひろ ${ }^{1}$, 佐藤 玄 $^{1}$

荒谷 彰男 ${ }^{1}$, 吉里 勝利 ${ }^{1,2}$

( ${ }^{1}$ 広島県地域結集型共同研究事業・組織 再生プロジェクト, ${ }^{2}$ 広島大学理学部生 物科学科発生生物学講座)

索引用語: 肝細胞, 星細胞, 增殖 肝臓は成人になっても再生力の強い臓器として知ら れている. 最近, JA. Rhim ら ${ }^{1)}$ K. Overturf ${ }^{2)} ら の$ グループにより, 正常なマウスの肝細胞を Alb-uPA ト ランスジェニックマウスやチロシン血漿を起こす突然 変異のマウスの肝蔵に移植すると，12回 ${ }^{1}$ または69回 ${ }^{2)}$
の細胞分裂が観察されたという報告がなされた。しか しながら, 現在のところ, 増殖した細胞が肝臓の幹細 胞であるのか, すべての肝細胞が高い増殖能を有する のかどうかについては不明である.

一方，これまで，コラゲナーゼで肝細胞を分離し シャーレで培養すると, せいぜい 1,2 回の細胞分裂 しか認められないことが常識とされてきた，私達は， 成体ラットの小型肝細胞が多く含まれる画分 (肝非実質 細胞画分)をDMEM にEGF, Nicotinamide, Ascorbic acid 2-phosphate, DMSOを添加した培地 (HCGM 培地)で培養すると, 小型肝細胞がコロニーを 形成しながらクローン性増殖することを見いだした また, 小型肝細胞のコロニー形成には非実質細胞の中 の星細胞の存在が必須であることがわかった. 私達は, 肝細胞を HCGM 培地を用いて非実質細胞や星細胞と 混合培養することにより，様々な肝細胞集団の増殖能 を評価する培養系を確立した。この方法を用いて，小 型肝細胞と, 通常培養に用いられている肝実質細胞の 増殖能を比較したところ, 小型肝細胞の方が, 肝実質 細胞に比べて, 約 2 倍高い増殖能を示した.このこと から, 小型肝細胞の中には, 幹細胞様の高い増殖能を 持つ細胞が多く存在するのではないかと考えている.

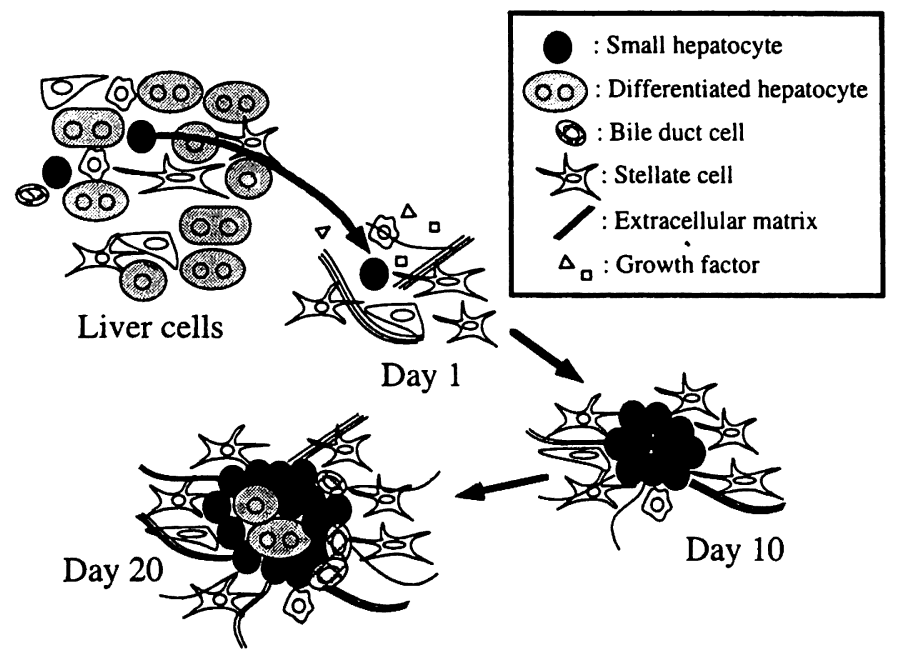

Fig. A schematic representation of the colony formation and differentiation of small hepatocytes. Many nonparenchymal cells surround single small hepatocytes, and especially stellate cells actively secrete extracellular matrices and growth factors (day 1). Hepatocytes start to divide and form colonies (day 10). At a final stage of culture, some cells differentiate into cells expressing either mature hepatocyte marker proteins or bile duct cell marker proteins (day 20). 
そこで, ラットの肝細胞を，FACS を用いて，大きさ， 自家虽光, 細胞内顆粒密度などをパラメーターとして 亜集団に分け，増殖能の比較を行った。 その結果，小 型肝細胞の中でも, より小型の肝細胞が最も増殖能が 高いことがわかった.

最近, 私達は, ヒトの肝臓においても, ラットと同 様にコロニーを形成する小型肝細胞が存在することを 示した4). 私達は, 将来的に, このような増殖能の高い 肝細胞の, 重篤な肝障害患者への肝細胞移植, 特異的 遺伝子欠損患者への ex vivo 遺伝子治療や, 人工肝蔵 への応用が期待されると考えており, 今後, 増殖性肝 細胞の性質をより詳細に調べていく予定である.

私達が用いている肝細胞増殖能評価系は, 肝細胞と 星細胞などの間葉系細胞との混合培養系であり, 肝細 胞の增殖能を最大限引き出すためには, 間葉系細胞ま たはこれらの細胞が作り出す因子が必要ではないかと 考えている，私達は，Swiss 3T3細胞も肝細胞の增殖を 促進することを見いだし，Swiss 3T3細胞が分泌する肝 細胞増殖促進因子としてプレイオトロフィンと HGF を 同定した5). 最近, 私達は, 傷害肝や培養星細胞におい てもプレイオトロフィンと HGF が高発現していること を明らかにし,さらに, 肝細胞をプレイオトロフィン,

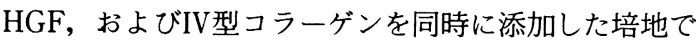
培養すると, 一部の肝細胞が顕著に高い増殖能を示す ことがわかった。これらのことから，肝細胞に対する 星細胞の増殖効果は, 星細胞が分泌する HGF, プレイ オトロフィンおよび細胞外マトリックスによって引き 起こされることが強く示唆された。

私達は, 現在, 肝細胞と星細胞の混合培養系を用い た肝蔵オルガノイドの作製を試みている，この混合培 養系は, 肝細胞の増殖に効果的であるだけでなく, 肝 細胞の単独培養系に比べて高いアルブミン分泌と薬物 代謝能を示しており, 将来, 人工肝臓への応用が期待 される。昨今, 国内でもいくつかの研究室で, 短期適 用型の代替臓器として, ブタの肝細胞を用いたハイブ リッド型人工肝臓の開発が進められている。もし， 上 卜肝細胞を大量に増殖させることができれば，異種間 による免疫反応やブ夕由来ウイルスの問題が解決され, より理想的なハイブリッド型人工肝臟を作ることが可 能であると考えている.

文 献：1）Rhim JA, Sandgren EP, Degen JL, Palmiter RD, and Brinster RL : Replacement of diseased mouse liver by hepatic cell transplanta- tion. Science 263:1149-1152, 1994 2) Overturf K, Al-Dhalimy M, Ou C-N, Finegold M, Grompe $M$ : Serial transplantation reveals the stem-celllike regenerative potential of adult mouse hepatocytes. Am J Pathol 151 : 1273-1280, 1997 3) Tateno C, Yoshizato K : Growth and differentiation in culture of clonogenic hepatocytes that express both phenotypes of hepatocytes and biliary epithelial cells. Am J Pathol 149: 1593-1605, 1996

4) Hino $H$, Tateno $C$, Sato $H$, Yamasaki $C$, Katayama S, Kohashi T, Aratani A, Asahara T, Dohi $\mathrm{K}$, Yoshizato $\mathrm{K}$ : A long-term culture of human hepatocytes which show a high growth potential and express their differentiated phenotypes. Biochem Biophys Res Com 256: 184-191, 1999 5) Sato H, Funahashi M, Kristensen DB, Tateno C, Yoshizato $\mathrm{K}$ : Pleiotrophin as a Swiss $3 \mathrm{~T} 3$ cell-derived potent mitogen for adult rat hepatocytes. Exp Cell Res 246:152-164, 1999

S4-10 ヒト肝細胞の増殖培養方法一ハイブリッド型人 工肝蔵への応用に向けての基礎的研究一

$$
\begin{aligned}
& \text { 日野 裕史 }{ }^{1} \text {, 小橋 俊彦 }{ }^{1} \text {, 片山 繁 }{ }^{1} \\
& \text { 浅原 利正 }{ }^{1} \text {, 土肥 雪彦 }{ }^{1} \text {, 立野 } \text { 知世年 }^{2} \\
& \text { 佐藤 玄 }{ }^{2} \text {, 吉里 勝利 }{ }^{2} \\
& \left({ }^{1} \text { 広島大学医学部外科学第 } 2 \text { 講座, }{ }^{2}\right. \text { 広島 } \\
& \text { 県組織再生プロジェクト })
\end{aligned}
$$

索引用語：ヒト肝細胞, 増殖培養, 人工肝臟

〔緒言〕当科ではハイブリッド型人工肝臓の基礎研究 として，ヒトの肝細胞を使用することを目指しヒト肝 細胞の增殖培養法を研究してきた。これにはいくつか の大きなメリットがある.

ひとつは, 異種動物細胞や癌細胞由来の株化した細 胞を使用することに伴う免疫学的問題がないこと. 次 に異種動物由来の未知のウイルスによる感染や発癌の 危険性がないこと。また機能が限られる株化した細胞 と異なり，正常肝細胞を用いるため多彩な肝固有機能 が発現でき, 解毒や代謝のみならず特に有用物質の供 給の点が期待できること.さらに本人の細胞の利用や 遺伝子学的な修飾や処理も可能で, そのまま体内に戻 せることから遺伝子治療や自家移植への応用, 補助藏 器としての体内埋込みが可能という利点もある。

しかし, 今までヒト肝細胞を使った研究が進んでこ なかったのは, その入手に困難と制約が伴うためであ る.この問題を克服するためにヒト肝細胞を増殖培養 することを考えた。 
ラットにおける肝細胞増殖培養法は, 立野らによっ て新しく開発された培地で培養することにより確立さ れた ${ }^{1 \sim 3)}$ が，われわれは，さらに培地に新たな幾つかの 工夫を加えることによりヒト肝細胞でコロニー形成が 可能な增殖培養法の開発に成功した。

〔材料と培養方法〕正常肝組織は広島大学医学部附 属病院において肝腫瘍の患者から手術前に同意を得て, 肝切除標本の非病変部から採取した。

肝組織は 2 ステップ酵素灌流法で細胞を分離し，低 速遠沈を行い大型の肝細胞を除去，次にこの上清の遠 沈を行い小型肝細胞と非実質肝細胞の沈殿を得た。こ の小型肝細胞画分の細胞を, 以下の添加物, $\mathrm{N}-2$-七ド ロキシエチルピペラジン-N'-2-エタンスルホン酸, L-プ ロリン, インスリン, デキサメタゾン, $\mathrm{NaHCO}_{3}$, 二 コチンアミド，上皮成長因子(EGF)，L-アスコルビン 酸 2 リン酸, ペニシリン $\mathrm{G}$ ，ストレプトマイシン，ゲ ンタマイシン，ヂメチルスルフォオキサイド(DMSO), ウシ胎児血清 (FBS), 新鮮なヒト血清(HS), 3T3細胞 調整培地 $(\mathrm{CM})$ を含んだダルベッコ修飾イーグル培地を 用いて培養した，細胞は $5 \times 10^{5} \mathrm{cell} \mathrm{s} / \mathrm{m} l$ の密度で播種 され $37^{\circ} \mathrm{C}, 5 \% \mathrm{CO}_{2}$ の条件で培養した。

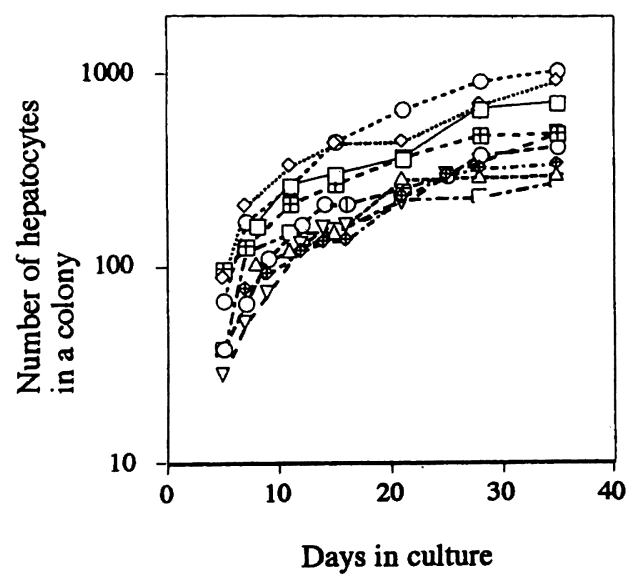

Fig. 1 Growth curves of colony-forming hepatocytes. Cells of the small hepatocyte fraction were cultured as in Figure 1. Hepatocyte colonies in the field were photo-graphed periodically up to 35 days. Nine curves were obtained by tracing the growth of 9 colonies on phase contrast microphotographs. Similar growth curves were obtained for each of them. The growth rate decreased with days in culture. Each symbol represents one colony traced.
〔結果と考察〕様々な濃度のヒト血清を培地に加え最 適化した条件を求めた。その結果 $5 \% \mathrm{FBS}$ と $10 \% \mathrm{HS}$ の 組み合わせが最も効果的で, さらに増殖率を改善する ために $3 \mathrm{~T} 3$ 細胞調整培地を濃度 $50 \%$ で加えた。この組み 合わせで最も増殖が認められた。これにより新鮮な正 常 HS にヒト肝細胞の成長を促進する効果があること をはじめて明らかにし，3T3細胞 CM から精製同定さ れた肝細胞成長促進因子，プレイオトロフィン4)はラッ 卜肝細胞のみならずヒト肝細胞にも有効と思われた。

ヒ卜肝細胞の増殖を位相差顕微鏡を通してコロニー を計測し成長曲線を得た。最も増殖したコロニーで肝

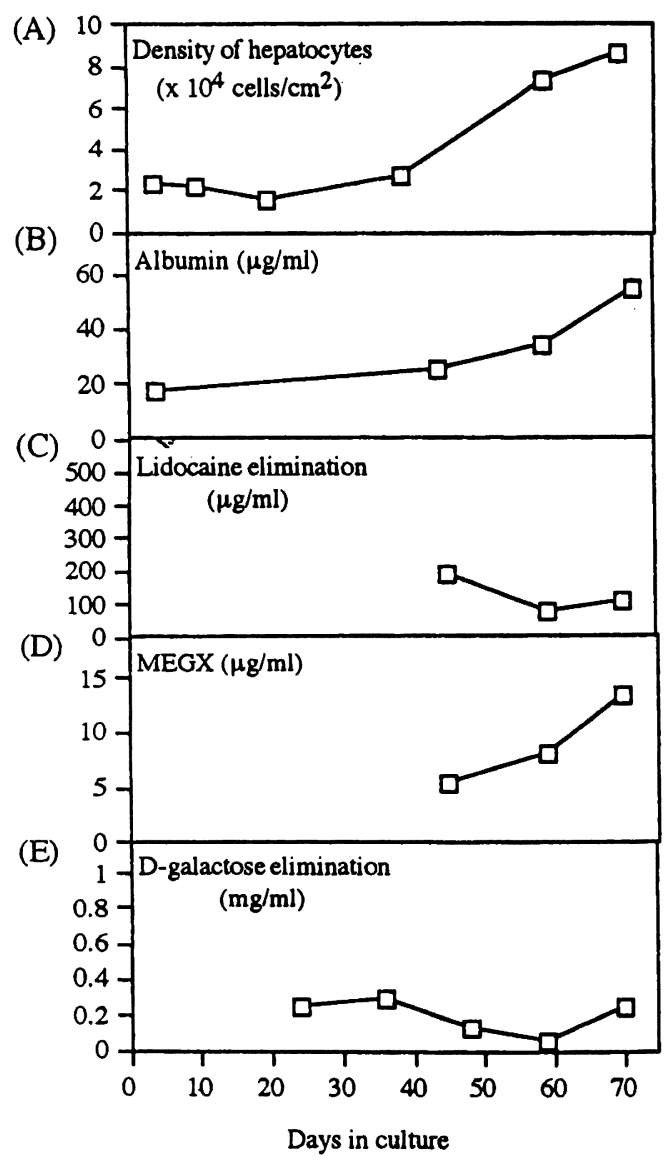

Fig. 2 Functional tests of human hepatocytes. Cells of the small hepatocyte fraction were seeded at $10^{5}$ cells $/ \mathrm{cm}^{2}$ on $13.5-\mathrm{mm}$ Celldesks were cultured for 72 days. Each point represents the mean of double cultures. (A)Density of hepatocytes, (B) Albumin secretion, (C) Lidocaine elimination, (D) MEGX formation, and (E) Galactose elimination. 
細胞数は31日間で17倍に増え，総肝細胞数は 1 日目か ら35日目までで2.8倍に達した。このことより非実質画 分に豊富に含まれる高い增殖能を示す肝細胞がラット と同様ヒトにも存在することが明らかになった。

コロニー形成細胞の特徵を各種マーカーの発現によっ て確認，35日目のコロニーの細胞は全て肝実質細胞特 有のアルブミン，トランスフェリン，そして $\alpha_{1}$-アンチ トリプシンを発現していた.

また，培養された肝細胞の機能をアルブミン分泌， リドカイン代謝(リドカインからモノエチルグリシンキ シリジン(MEGX)への代謝で肝細胞のチトクロム P450 活性を評価)，D-ガラクトース代謝で評価した，肝細胞 は培養中アルブミンを生産し続けそのレベルは72日目 で13.5ng/cell/3dayであった。リドカインの代謝もそ の能力は徐々に低下したが70日目でも確認できた。ま た $1 \mathrm{mg} / \mathrm{ml}$ の D-ガラクトースを負荷し70日間代謝させ た. その值は70日目で $0.10 \mathrm{mg} / 1.7 \times 10^{5}$ hepatocytes で あった。

これらの結果から長期間培養のヒト肝細胞は, 短期 間培養のブタ肝細胞の機能に匹敵するレベルを 2 カ月 間も維持していることを証明した。

【結語〕われわれが開発したヒト肝細胞増殖培養法に よって, 初めて長期間にわたってヒト肝細胞の増殖培 養が可能となった。しかも，その培養肝細胞は正常の 機能を発現していることが明らかになった。この培養 法をさらに発展させることにより，肝細胞移植による 肝細胞置換, 遺伝子治療, ハイブリッド型人工肝臓な どの途が大きく開けると考える.

文 献：1) Tateno C, Yoshizato K : Long-term cultivation of adult rat hepatocytes that undergo multiple cell divisions and express normal parenchymal phenotypes. Am J Pathol 148:383-392, 1996 2) Tateno C, Yoshizato K : Growth and differentiation in culture of clonogenic hepatocytes that express both phenotypes of hepatocytes and biliary epithelial cells. Am J Pathol 149: $1593-1605,1996$ 3) Tateno C, Yoshizato K : Growth potential and differentiation capacity of adult rat hepatocytes in vitro. Wound Repair Regen 7(1):36-44, 1999 Jan-Feb 4) Sato H, Hunahashi M, Kristensen DB, Tateno C, Yoshizato $\mathrm{K}$ : Pleiotrophin as a Swiss $3 \mathrm{~T} 3$ cell-derived potent mitogen for adult rat hepatocytes. Exp Cell Res 246(1) : 152-64, 1999 Jan 10
S4-11 グルタミン合成酵素導入 HepG2細胞をリアク ターとしたハイブリッド人工肝の機能と効果 絵野沢 伸 ${ }^{1}$, 宮下 智之 ${ }^{1}$, 田村 明彦 ${ }^{1}$ 鈴木 盛一 ${ }^{1}$, 雨宮 浩 ${ }^{1}$, 大政 健史 ${ }^{3}$ 菅 健一 ${ }^{3}$, 高村 政範 ${ }^{2}$, 松村外志張 ${ }^{2}$ (1国立小児病院小児医療研究センター, ${ }^{2}$ 大阪大学大学院工学研究科, ${ }^{3}$ 明治乳業 細胞工学センター)

索引用語 : ハイブリッド人工肝, HepG2, 遺伝子導 入

〔目的〕当グループではハイブリッド型人工肝に適し た細胞株の構築をめざし，その初段階として肝性昏睡 の主原因である血中アンモニアの選択的除去を可能と する遺伝子組換細胞の作出を試みている，上卜肝芽細 胞腫由来 HepG2は野生株でアンモニア代謝能を欠失し ている11.そこでグルタミン合成酵素によって機能を付 加した.ささらに回流式培養装置(キグナス; Cygnus) ${ }^{2)}$ より109 10細胞レベルの大量培養を行い, 形質転換細胞 を用いたハイブリッド人工肝構築の基礎検討を in vitro, in vivoで行った.

〔方法〕 pBK-CMV の multicloning site に $\mathrm{CHO}$ 細 胞由来のグルタミン合成醉素(GS)遺伝子を組込み, HepG2細胞株に GS 遺伝子を導入, 次いで培地中の GS 阻害剂 MSX 濃度を段階的に上昇させて遺伝子増幅 を行った。キグナス (内容積 $550 \mathrm{~cm}^{3}$ ) 内には細胞接着基 質として焼成済ガラス瀻維 $\left(1,500 \mathrm{~cm}^{2}\right)$ を装填した。 新鮮培地の添加は $1 l /$ 日, 溶存酸素は $40 〜 70 \%$ を維持 した。細胞は $5 \times 10^{7}$ 個を播種し109日間培養した。in vivo 実験では家畜ブ夕 ( $25 \mathrm{~kg}$ 前後)で虚血性肝不全モデ ルを作成し虚血後 3 時間より血獎をキグナスに導入し 体内に戻した。対照実験では細胞を有しないキグナス を用いた。種々の臨床検査データは心停止まで経時的 に測定した。

〔結果・考察】得られたGS-HepG2のアンモニア代 謝能は, 初発アンモニア濃度 $1 \mathrm{mM}$, 静置培養下で $1.4 \times$ $10^{-14} \mathrm{~mol} / \mathrm{cell} / \mathrm{h}$ の值となり, 初代肝の約 $1 / 7$ の活性で あった。キグナスによる大量培養時にも同様の活性が 得られた. 肝不全ブタへの適用では肝不全惹起後12時 間の時点でアンモニアと凝固系 (ACT, HPT, APTT) で改善傾向が見られた。後者における GS-HepG2の効 果は, 凝固因子の補給というょりはむしろ肝不全にお ける消費性凝固障害をなんらかの機構で抑制している ためではないかと考えている. 


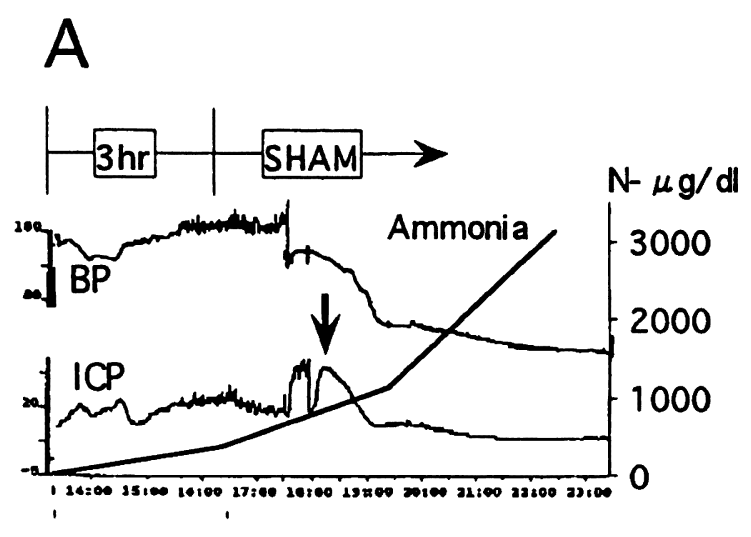

B

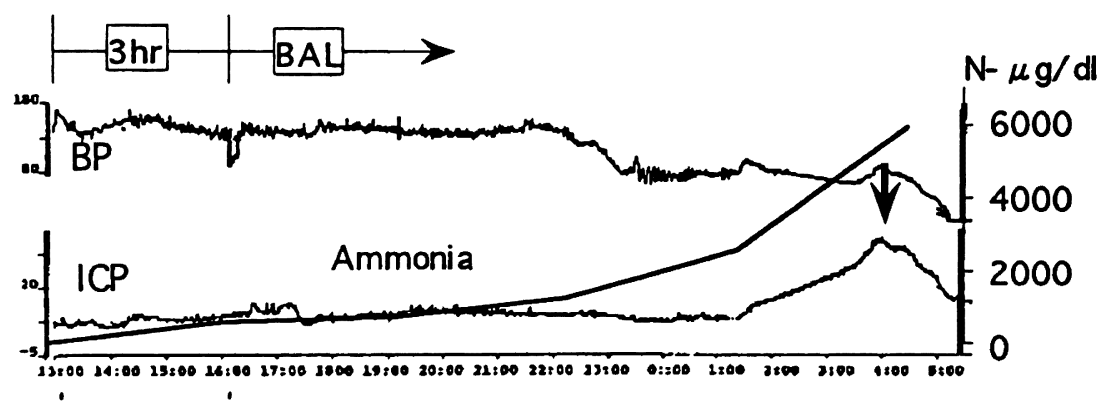

Fig. Typical profiles of maximum blood pressure (BP), intracranial pressure (ICP), and blood ammonia with cell-free control (A) and GS-HepG2 bioreactor-treated pig (B). Three hours after the completion of ischemic liver failure, extracorporeal blood circulation was started with circulatory flow bioreactor (Cygnus) with or without GS-HepG2 cells. Arrows indicate peaks of intracranial pressure, followed by decrease of blood pressure.

文 献：1) Enosawa S, Suzuki S, Kakefuda, T Amemiya $\mathrm{H}$ : Examination of 7-ethoxycoumarin deethylation and ammonia removal activities in 31 hepatocytes cell lines. Cell Transplant $5: \mathrm{S} 39-40$, 1996 2) Nemoto A, Hirota-Iwai Y, Miyazaki Y, Nakamichi $N$, Ito $M$, Tokiwa $T$, Kodama $M$, Matsumura $\mathrm{T}$ : Evaluation of a fixed-bed type bioreactor system using recombinant $\mathrm{CHO}$ cells producing human transferrin. Animal Cell Technology: Basic and Applied Aspects, Kluwer Academic Publishers, Dordrecht. in press.
S4-12 肝細胞を用いたバイオ人工肝による急性肝不全 の治療に必要な肝細胞数の検討一D-galactosamine 誘導急性肝不全ラットに対する肝細胞腹腔 内移植の結果から一

$$
\begin{aligned}
& \text { 澤 雅之 }{ }^{1}, \text { 間宮 規章 }{ }^{1}, \text { 星 智和 }{ }^{1} \\
& \text { 小原 充裕 }{ }^{1}, \text { 葛西 真一 }{ }^{1} \\
& \text { ('旭川医大第 } 2 \text { 外科) }
\end{aligned}
$$

急性肝不全に対する究極的な治療法として肝移植が 試みられ，良好な成績が得られている。近年の急激な 移植症例数の増加は, 深刻なドナー不足をもたらし, 遊離肝細胞を代謝リアクターとして用いるバイオ人工 肝の開発が盛んである．欧米ではすでに移植用ドナー 肝入手までの bridge-use としてバイオ人工肝の臨床応 用もしくは肝細胞移植が試みられ，その成功例が報告 
されている．しかし，必要肝機能補助量が肝障害の程 度によって異なることなどにより，バイオ人工肝の装 置内にどの程度の肝細胞量が必要なのかいまだに議論 の分かれるところである．本研究では，D-gal 誘導急性 肝不全ラットに対して被包化肝細胞の腹腔内移植を行 い, その生存率から必要肝細胞数を検討したので報告 する.

〔方法〕体重約 $200 \mathrm{~g}$ の雄性 Wistar ラットの肝臟より

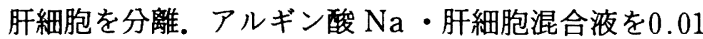
$\mathrm{NCaCl}_{2}$ に滴下してアルギン酸 $\mathrm{Ca}$ 包埋肝細胞 beads を 作成し, D-gal $(1.5 \mathrm{~g} / \mathrm{kg})$ 腹腔内投与12時間後の同系 ラットの腹腔内に移植 (G-I $: 1 \times 10^{7}$ 個, G-II : $1 \times$ $10^{6}$ 個，G-III : $1 \times 10^{5}$ 個，G-IV : アルギン酸 $\mathrm{Ca}$ 包埋肝 細胞培養液 $4 \mathrm{ml}, \mathrm{G}-\mathrm{V}:$ アルギン酸 $\mathrm{Ca}$ 包埋死滅肝 細胞， G-VI：肝細胞を含まないアルギン酸 $\mathrm{Ca}$-beads). 移植後経時的な血清 GOT, LDH 值の計測および生存 率の記録を行い，肝臓の組織学的検索も併せて行った。

〔結果〕 D-gal 投与後上昇していた G-I ・II生存 ラットの血清肝逸脱酵素値 (GOT, LDH) は, 肝細胞移 植後すみやかに低下した。一方， G-IV・V・VIでは， 血清肝逸脱醉素值の上昇が継続し，その $85 \%$ 90\%は 移植後 60 時間以内に死亡した. D-gal 投与後 1 週間の 生存率は G- I : $80 \%$, G-II : $60 \%, \mathrm{G}-\mathrm{III}: 30 \%, \mathrm{G}$ $-\mathrm{IV}: 15 \%, \mathrm{G}-\mathrm{V}: 10 \%, \mathrm{G}-\mathrm{VI}: 10 \%$ と移植肝細胞数 の増加に伴い改善傾向を認めたが，肝細胞培責液の腹 腔内投与や死滅肝細胞およびアルギン酸 Ca-beads のみ の移植では生存率の改善は得られなかった。また，肝 細胞移植時期を D-gal 投与 24 時間後に遅延させた場合 には救命効果を認めなかった。移植後36時間における 肝臓の組織学的検索では, G- I ・II・IIIの生存ラット は点状もしくは小塊状の肝細胞壊死像を呈していたの に対し, G-IV・V・VIは広範な肝細胞壊死像を呈して いた。

【考察〕各種実験的急性肝不全に対する肝細胞移植 の生存率改善効果ならびにバイオ人工肝を用いた血液 もしくは血槳灌流による生存期間の延長が報告されて いる.しかし，いずれの場合も移植肝細胞数もしくは 装置内の肝細胞数が全肝の肝細胞数の $5 \%$ 以下であり， 急性肝不全救命に必要な肝細胞数が不明であった。本 研究では，D-gal 誘導急性肝不全ラットの救命には $1 \times$ $10^{7}$ 個程度の肝細胞数が必要であることが判明した。 今 後，様々な肝不全モデルでの同様な検討および治療開 始時期の検討が必要であり, 肝不全の重症度に即した バイオ人工肝の作成が重要と考える.
〔結語〕D-gal 誘導急性肝不全ラットの救命には $1 \times$ $10^{7}$ 個 (全肝の肝細胞数の約 $2 \%$ ) 程度の viable な肝細 胞が必要であり, 肝細胞移植の効果発現には肝細胞の 移植時期も重要な因子であることが判明した。

\section{S4-13 異種全肝体外灌流型肝補助システムの開発の現} 況と問題点

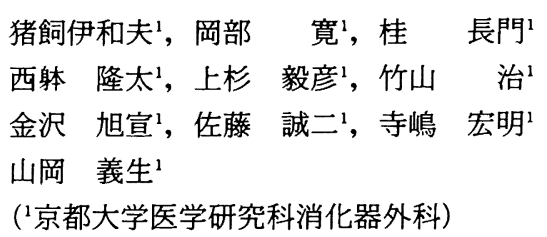

索引用語：肝補助システム, 全肝灌流, 異種臟器

急性肝不全の治療のために分離肝細胞を用いたハイ ブリッド型人工肝臓の開発が積極的に進められている。 劇症肝不全に見られるような急速に進行する肝性昏睡 に対応するためには，より高い肝補助機能を持つ肝補 助装置が必要と考えられる。我々はハイブリッド型人 工肝臓より高い機能を持つ肝補助装置の開発を目的に, ブタ摘出全肝を用いた異種全肝体外灌流型肝補助シス テムの開発を進めている.

ブタ全肝を体内にて急速冷灌流後に摘出し, 肝動脈 及び門脈より灌流する全肝体外灌流システムを作成し た。灌流システムには摘出肝臓の機能を維持するため に人工肺・熱交換器・ローラーポンプ・リザーバーか らなる閉鎖回路を用いた。従来のブタ全肝体外灌流の 報告ではブ夕新鮮血をもちいた同種血灌流においても わずか数時間しか灌流が維持できないとされている。

しかし，本システムにおいては，肝摘出時の冷保存時 間の短縮 (30分以内) - 生理的灌流圧や酸素分圧の設定 -PGE1の持続投与により, ブタ血液で灌流する同種肝 灌流においては24時間以上の安定した灌流が可能であっ た。異種血であるヒト新鮮血による灌流では 9 時間ま では安定した灌流が可能であったが，9時間以降は超 急性拒絶反応のため次第に肝動脈圧の上昇や浸出液の 增加を認めるようになり, 灌流の維持は困難であっ $た^{1-3)}$. 灌流可能な 9 時間の範囲内ではアンモニア・リ ドカインクリアランス, ガラクトース最大代謝速度な ど低分子物質の代謝機能や胆汁分泌は同種ブタ血で灌 流した肝臟と同等に維持された4).

肝不全モデルとして全肝血流遮断十門脈・下大静脈 シャントを行ったビーグル犬を用いて，このブタ全肝 灌流システムと交差灌流を行うことにより肝補助シス テムとしての機能評価を行った。ブタ全肝灌流は約 10 
時間維持することが可能であり，肝不全モデル犬の血 清アンモニア值, 総胆汁産量, アミノ酸フィッシャー 比は有意に改善した。また，交差灌流を行うことによ り生存時間は13時間から26時間と有意に延長した。さ らに, 前臨床試験として霊長類である健常七七との交 差灌流を行うと，補体活性化に起因すると考えられる 溶血が惹起されること，この溶血による腎不全を回避 することが重要であることが明らかとなった。

今後, 異種全肝型肝補助システムの臨床応用をめざ すためには,さらに長時間肝補助機能を維持し，また 宿主側への影響を軽減するために補体活性化を抑制す る工夫を行う必要があると考えられる。

文 献：1) Terajima $H$, Shirakata $Y$, Yagi $Y$, Mashima M, Shinohara H, Satoh S, Arima Y, Gomi T, Hirose T, Takahashi R, Ikai I, Morimoto $\mathrm{T}$, Inamoto $\mathrm{T}$, Yamamoto $\mathrm{M}$, Yamaoka $\mathrm{Y}$ : Successful long-term xenoperfusion of the pig liver : continuous administration of prostaglandin E1 and insulin. Transplantation 63:507-512, 1997 2) Satoh S, Terajima H, Yagi T, Kanazawa A, Shinohara T, Gomi T, Uesugi T, Yoneyama T, Ikai I, Takahashi R, Yamamoto M, Yamaoka $Y$ : Humoral injury in xenoperfused porcine livers with human whole blood. Transplantation 64 : 1117-1123, 1997 3) Yagi T, Ikai I, Terajima H, Satoh S, Kanazawa A, Shinohara H, Uesugi $T$, Yoneyama T, Gomi T, Takahashi R, Yamamoto $\mathrm{M}$, Inamoto $\mathrm{T}$, Yamaoka $\mathrm{Y}$ : The protective effects of prostaglandin E1 on sinusoidal endothelial cells in xenogeneic pig liver perfusion. J Surg Res $71: 28-34,1997$ 4) Uesugi T, Ikai I, Yagi T, Satoh S, Kanazawa A, Yoneyama T, Takeyama $O$, Nishitai $R$, Katsura $N$, Okabe $H$, Terajima H, Iwata $\mathrm{H}$, Yamaoka $\mathrm{Y}$ : Evaluation of ammnia and lidocaine clearance and galactose elimination capacity of xenoperfused pig livers using a pharmacokinetic analysis. Transplantation (in press)

\section{S4-14 劇症肝炎の臨床現場から人工肝に期待するもの}

$$
\text { 与芝 真 }
$$

索引用語: バイオ人工肝, 人工肝補助, 血槳交換

〔緒言〕現在欧米でも我が国でもブタ肝などの生体材 料を使用したいわゆるバイオ人工肝の研究が推進され ている．特に米国では Demetriou の考案したバイオ人
工肝が市販され，現在 I 相試験が終了し，II相試験が 行われている。一方，我が国では血槳交換 (以下 PE)が 普及しており，これに中分子量以下のを非選択に高能 率に除去するいわゆ “high performance membrane” を使用した血液滤過透析(HDF)ないし持続滤過透析 (CHDF)が施行されており, 次世代の肝補助として定 着しつつある。

$\mathrm{PE}+\mathrm{HDF}$ の肝補助能力は強大で，60パック(約 4.8 l)の凍結血槳を使用した PE と $40 l$ の置換液を使用した $\mathrm{HDF}$ (全排液量 $400 l$ )の併用という最大能力を発揮すれ ばほとんど肝機能の廃絶した肝不全症例であっても昏 睡から完全に覚醒し，意識清明に維持することも不可 能ではない ${ }^{1)}$.しかし，PEでは大量の正常人血漿を使 用する点に資源上の問題がある. 今回筆者は自験例に おける $\mathrm{PE}+\mathrm{HDF}$ の血槳成分の供給能と尿素や芳香族 アミノ酸等の除去特性を検討し，また，Demetriou ら のバイオ人工肝の第 I 相試験の文献的考察からバイオ 人工肝が $\mathrm{PE}+\mathrm{HDF}$ に代り得る能力を保有するか否か を検討した。

〔方法〕自験の劇症肝炎患者で, $\mathrm{PE}+\mathrm{HDF}$ 治療を 受けた患者において PEによる血漿成分の補給量と HDF における尿素および芳香族アミノ酸の排除量, $\mathrm{PE}+\mathrm{HDF}$ 前後での血液生化学データの比較を行った。 Demetriou のバイオ人工肝の成績は報告論文 ${ }^{2}$ から解析 した.

〔成績〕 60パックの正常人血墏を使用する PEでは 168〜 264g のアルブミン，9.6〜21.6g のフィブリノー ゲン, 240〜 480mg のプロトロンビン, 816〜 1, $440 \mathrm{mg}$ の AT III, 691〜816mg のプラスミノーゲンの補給が可 能である．また， $20 l$ の置換液を用いた $\mathrm{HDF}$ (総排液量 $186 l$ ) では15g の BUN, 約49のグルタミン, $350 \mathrm{mg}$ 余 のメチオニン, $1.5 \mathrm{~g}$ 余のタイロシン, $1.2 \mathrm{~g}$ 余のフェニ ルアラニン， $500 \mathrm{mg}$ 弱のトリプトファンの除去が可能 であり,この除去量は基本的に血中濃度に依存した(表 $1)$.

$\mathrm{PE}+\mathrm{HDF}$ の前後で比較すると，プロトロンビン時間， アルブミンなど肝合成系の指標は大幅に改善し, ビリ ルビン, 芳香族アミノ酸など解毒代謝系の指標も大幅 に低下した。

一方, Demetriou のバイオ人工肝の第 I 相治験の成 績では, 治療を40〜90時間施行した後頭蓋内圧の低下 には一定の効果を示すもののフィブリノーゲンや第 V 因子に低下を示しており，少なくとも肝合成能の補償 の点では限界があることが明らかとなった。 
表 1 PE + HDF の肝機能代償能力. 解毒代 償性の補正能力(除去能, 1 回 $20 l$ の置換液を 用いた HDF の場合, 全排液量 $186 l$ )

\begin{tabular}{lrr}
\hline & 血清濃度 & \multicolumn{1}{c}{ 除去量 } \\
\hline 尿素窒素 & $(1,388 \mathrm{nmol} / \mathrm{m} l)$ & $15,064 \mathrm{mg}$ \\
グタミン & $(486 \mathrm{nmol} / \mathrm{m} l)$ & $3,985 \mathrm{mg}$ \\
メチオニン & $(45 \mathrm{nmol} / \mathrm{m} l)$ & $358 \mathrm{mg}$ \\
タイロシン & $(116 \mathrm{nmol} / \mathrm{m} l)$ & $1,575 \mathrm{mg}$ \\
フェニルアラニン & $(104 \mathrm{nmol} / \mathrm{m} l)$ & $1,254 \mathrm{mg}$ \\
トリプトファン & $(35 \mathrm{nmol} / \mathrm{m} l)$ & $490 \mathrm{mg}$ \\
\hline
\end{tabular}

〔考察〕現在我が国で普及し始めた PE + HDF の臨床 効果と比較の上で Demetriou の考案したバイオ人工肝 の効果を解析した. PE+HDF は肝合成能および解毒能 の効果に優れ, 肝機能の高度に廃絶した肝不全患者も 意識清明下に維持することが可能である. 実際その血 槳成分の補給能力や尿素窒素やアミノ酸の除去能力は 強大であり,これが PE+HDF の優れた肝補助能力の 根拠となっていると考えられる. 表 1 からはこの除去 量は血中濃度とほほ相関していることから大量に蓄積 したとしても十分対応する能力があることが推定され
る.さらに, この除去能は使用する置換液を増加させ れば除去量に相関して増加する点では敢えて他の方法 の応用の必要性は感じられない。

一方，バイオ人工肝に脳圧穴進に対して有効のよう だが, 回路内に活性炭による吸着装置が組み込まれて おり，あるいはこの効果が大きく作用している可能性 がある. また， PE 施行の際のヒト血漿の大量使用に対 する補完的能力の点ではフィブリノーゲンや第 $\mathrm{V}$ 因子 など肝合成系の指標は治療後低下しており，その代償 能力は低いことが推定され, 臨床現場の期待には必ず しも答えられる成績とは言えなかった。

文 献：1) Yoshiba M: Recent Progress in the Treatment of Fulminant Hepatic Failure in Japan. J Infect Chemother 4:41-49, 1998 2) Watanabe FD, Mullon C J-P, Hewitt WR, Arkadopoulos N, Kahaku E, Eguchi S, Khalili T, Arnaout W, Shackleton CR, Rozga J, Solomon B, Demetriou AA : Clinical Experience with a Bioartificial Liver in the Treatment of Severe Liver Failure. Annals of Surgery 225(5): 484-494, 1997 